REALA, número 14, octubre-marzo de 2020

Sección: COMUNICACIONES Y COMENTARIOS JURISPRUDENCIALES

Recibido: 20-03-2020

Modificado: 10-07-2020

Aceptado: 17-07-2020

DOI: https://doi.org/10.24965/reala.i14.10784

Páginas: 180-200

\title{
Elementos comunes y diferencias de la respuesta regulatoria a los retos del alojamiento colaborativo y el alquiler de corta duración: un análisis de los títulos de intervención y las estrategias comunes en CC.AA y municipios
}

\section{Common elements and differences in the regulatory response to peer-to-peer accommodation and short-term rentals: an analysis of the title of intervention and the common strategies in regional and local institutions}

Andrea Kruithof Ausina Universitat de València (España) andrea.kruithof@uv.es

\begin{abstract}
NOTA BIOGRÁFICA
Licenciada en Ciencias Políticas y de la Administración por la Universitat de València, y ha cursado el Máster de Análisis Político por la Universidad Complutense de Madrid. Actualmente es investigadora en la Cátedra de Economía Colaborativa y Transformación Digital de la Universitat de València, donde se especializa en plataformas digitales de alquiler turístico y su regulación.
\end{abstract}

\begin{abstract}
RESUMEN
La irrupción de la economía digital ha implicado grandes transformaciones para los distintos sectores económicos. Los cambios tecnológicos y la rapidez en los intercambios de información han permitido que proliferen nuevos modelos de negocio, caracterizados por una interacción más directa entre los usuarios y los «vendedores». El «fenómeno Airbnb» es una preocupación cada vez mayor en los distintos territorios del Estado, lo que ha tenido un impacto significativo en el crecimiento de la regulación específica en este campo. En el presente artículo analizamos las similitudes y divergencias regulatorias entre los distintas Comunidades Autónomas y Ayuntamientos, intentando resumir a grandes rasgos los elementos más característicos de la normativa en este ámbito.
\end{abstract}

\section{PALABRAS CLAVE}

Viviendas de uso turístico; Airbnb; alojamiento colaborativo; alquiler de corta duración; regulación autonómica.

\begin{abstract}
The irruption of digital economy has implied great transformations for the different economic sectors. Technological changes and the promptness of information exchange has allowed for new business models to appear, characterised by a more direct interaction between users and sellers. The «Airbnb phenomenon» is a growing concern among regions within Spain, which has had a significative impact in the increasing development of specific regulation in this field. In this paper, we analyse the regulatory similarities and divergences among the regional and local approaches, trying to sum up the thrust of the legislation in this area.
\end{abstract}

\section{KEYWORDS}

Vacation rentals; Airbnb; Peer-to-peer accommodation; short-term rentals; regional regulation. 
REALA. Nueva Época - N. 14, octubre 2020 - ISSN: 1989-8975 - DOI: https://doi.org/10.24965/reala.i14.10784 - [Págs. 180-200]

Elementos comunes y diferencias de la respuesta regulatoria a los retos del alojamiento colaborativo y el alquiler de corta duración...

Andrea Kruithof Ausina

\begin{abstract}
SUMARIO
INTRODUCCIÓN. 1. REGULACIÓN ESPECÍFICA. 2. LIMITACIONES URBANÍSTICAS. 2.1. TIPOLOGÍA DE EDIFICACIÓN Y UBICACIÓN DENTRO DE LAS VIVIENDAS. 2.2. COMUNIDAD DE PROPIETARIOS. 2.3. UBICACIÓN GEOGRÁFICA. 3. LIMITACIONES DE LA ACTIVIDAD. 3.1. REQUISITOS TÉCNICOS MÍNIMOS. 3.2. CAPACIDAD MÁXIMA. 3.3. MANTENIMIENTO Y LIMPIEZA. 3.4. TIEMPO PERMITIDO DE ALQUILER. 3.5. NORMAS DE CONVIVENCIA. 3.6. CESIÓN POR ESTANCIAS/ALQUILER POR HABITACIONES. 3.7. PERMISO DE INICIO DE ACTIVIDAD. 4. REGISTRO AUTONÓMICO DE ACTIVIDAD. ANEXO I. TABLA RESUMEN DE REGULACIONES AUTONÓMICAS Y MUNICIPALES. REFERENCIAS BIBLIOGRÁFICAS.
\end{abstract}

\title{
INTRODUCCIÓN
}

Los cambios tecnológicos y la rapidez en los intercambios de información han facilitado que proliferen nuevas formas de contratación y organización de la actividad económica, de modelos de negocio que hacen frente a nuevas necesidades sociales, caracterizados por una interacción más directa entre usuarios y proveedores de servicios, «abriendo la puerta a la participación activa de los particulares (peers) en la realización de transacciones económicas» (Herrero, 2017: 151).

Es el caso de la «economía de plataformas», en principio pensada para el alquiler de bienes infrautilizados pero que rápidamente se ha extendido a la práctica totalidad de los sectores productivos y ha segmentado y ocupado parte de sus mercados (Del Águila, 2016: 217-228). El raudo desarrollo de las plataformas P2P (peer to peer en inglés) se debe a dos factores principales: las innovaciones tecnológicas que suponen y la flexibilidad de los proveedores (Zervas et al., 2017: 687).

A medida que se ha ido desplegando, la acepción de "economía colaborativa» para englobar el fenómeno de manera acrítica ha perdido progresivamente apoyo entre los expertos, con cada vez más voces críticas que hacen hincapié en la dimensión lucrativa de algunas de las actividades que aquí se incluyen, entre ellas, la del hospedaje turístico. De hecho, para Guillén «el intercambio por dinero altera la finalidad colaborativa propiamente dicha, al derivarse hacia un alquiler de vivienda o de habitación con un intermediario que en la mayoría de los casos se lleva una comisión por la prestación de dicho servicio» (Guillén, 2018: 21). Asimismo, algunos de los estudios existentes apuntan ya a la dimensión profesionalizada del fenómeno (Gil y Sequera, 2018: 15-32), alejándolo del «aprovechamiento ocasional peer to peer de un recurso habitacional» (Nogueira; 2018: 233).

Para el mercado inmobiliario, la aparición de la economía digital implicaba una oportunidad de revitalización. La crisis de 2008 dejaba el entonces principal motor económico de España en un estado maltrecho, con grandes stocks de viviendas vacías y con poca salida al mercado. Frente a la dificultad de sacar un rendimiento económico de las viviendas a través de la compraventa, el alquiler turístico se erguía como una alternativa para rentabilizar los bienes inmuebles. En el universo «Airbnb» ello permitía, además, la explotación de bienes sin la existencia de intermediarios y escapando a las exigencias -impositivas y técnicas- de un sector muy tasado (Guttentag, 2015: 1.192-1.217; Artigot, 2017: 189-206), dada la imprecisión regulatoria de la cesión por particulares y empresas de viviendas y alojamientos con finalidad turística, que se consideraban «arrendamiento para uso distinto al de la vivienda» y venían regidos por la Ley 20/1994, de 24 de noviembre, de Arrendamientos Urbanos (Sánchez y García, 2018: 19-54).

El boom de la vivienda turística en viviendas particulares no ha estado exento de conflicto. Como explica Artigot, por una parte, «la interacción en el mercado entre participantes "regulados" y participantes "no reglados" ha generado conflictos desde el punto de vista del derecho de la competencia y de la regulación del mercado» (Artigot, 2017: 189). Asimismo, continúa la autora, la incorporación del «universo Airbnb» a los servicios turísticos implica un desafío doble, que se manifiesta tanto a nivel individual -molestias y pérdida de valor de las propiedades-, como a nivel agregado, a través de toda una serie de externalidades negativas (Artigot, 2018: 163). Las asociaciones de hosteleros han señalado la expansión del fenómeno como una competencia desleal, que incide de manera significativa en sus ingresos (Zervas et al., 2017: 687-705), a la vez que exigen que dichas viviendas cumplan con normativas equiparables a las del alojamiento hotelero (calidad de la oferta y requisitos técnicos mínimos que los inmuebles, exigencias fiscales e impositivas, garantías para los consumidores, restricciones urbanísticas, etc.).

Por otra parte, no es baladí el impacto de las viviendas de uso turístico (VUT) y su explotación a gran escala en los modelos urbanísticos y en el propio diseño de las ciudades y en la calidad de vida de los ciuda- 
REALA. Nueva Época - N. 14, octubre 2020 - ISSN: 1989-8975 - DOI: https://doi.org/10.24965/reala.i14.10784 - [Págs. 180-200]

Elementos comunes y diferencias de la respuesta regulatoria a los retos del alojamiento colaborativo y el alquiler de corta duración...

danos. Si bien plataformas digitales como Airbnb se autodefinen como un servicio para «compartir hogares», algunos autores critican que han facilitado que el hospedaje turístico se instale en zonas residenciales, a través de la cooptación de inmuebles cuyo uso previsto inicial no era el turístico pero que sin embargo resulta mucho más rentable para los propietarios, agudizando, en consecuencia, problemas relativos al acceso a la vivienda -especialmente para grupos vulnerables- y a la turistificación de las ciudades (Gurran y Phibbs, 2017: 80-92).

La modificación de la Ley 29/1994, de 24 de noviembre, de Arrendamientos Urbanos por la Ley 4/2013, de 4 de junio, de medidas de flexibilización y fomento del mercado del alquiler de viviendas, se hace eco de estas dificultades y marcará un punto de inflexión por lo que respecta a la permisibilidad regulatoria con las viviendas turísticas. Así lo dice en su preámbulo:

«En los últimos años se viene produciendo un aumento cada vez más significativo del uso del alojamiento privado para el turismo, que podría estar dando cobertura a situaciones de intrusismo y competencia desleal, que van en contra de la calidad de los destinos turísticos, de ahí que la reforma de la Ley propuesta los excluya específicamente para que queden regulados por la normativa sectorial específica o, en su defecto, se les aplique el régimen de los arrendamientos de temporada, que no sufre modificación».

Dicha modificación introduce un nuevo apartado en el artículo 5 por el que se excluye de la aplicabilidad de la LAU el uso turístico de las viviendas (art.5.e), derivándolo a la normativa sectorial específica:

«La cesión temporal de uso de la totalidad de una vivienda amueblada y equipada en condiciones de uso inmediato, comercializada o promocionada en canales de oferta turística y realizada con finalidad lucrativa, cuando esté sometida a un régimen específico, derivado de su normativa sectorial» (art. 5.e).

Con este nuevo redactado, el alquiler de corta duración pasaba a entenderse como una actividad económica, la cual podía verse sujeta a toda una serie de exigencias. Con ello, se abría la puerta a que las distintas Comunidades Autónomas generasen sus propios marcos de referencia normativa, aunque ya previamente algunas comunidades (entre las que se encuentra la Comunidad Valenciana) habían considerado la cuestión. La evolución de las normativas autonómicas ha pasado por distintas fases de evolución regulatoria, que se han caracterizado por una interpretación cada vez más restrictiva, en la que no solo se tienen en cuenta las reivindicaciones en el sector del turismo, sino que entran cuestiones de seguridad ciudadana, convivencia vecinal o sostenibilidad urbana, con una centralidad creciente de la «capacidad de carga de los recursos turísticos» (Nogueira, 2018: 234). Ello sin olvidar que «cualquier restricción que se establezca ha de poder ser justificada a la luz de la Directiva de Servicios con base en su oportunidad, necesidad y oportunidad» (Boix, 2018: 279). En este mismo paradigma, el papel otorgado a las entidades locales también ha ido cobrando protagonismo.

El presente documento pretende recopilar las principales características de estas regulaciones de la vivienda turística con una perspectiva autonómica y municipal, identificando los principales elementos en común y de divergencia.

\section{REGULACIÓN ESPECÍFICA}

El sector del alojamiento de corta estancia ha experimentado, como se argumentaba en el apartado anterior, grandes modificaciones en los últimos años, si bien el hospedaje turístico tiene un largo recorrido en nuestro Estado. Ello tiene consecuencias en cómo se trata la cuestión, si bien es cierto que prácticamente hay consenso a la hora de tratar las viviendas turísticas como un fenómeno novedoso -o más bien, lo es la percepción sobre lo disruptivo de su expansión- que merece un tratamiento diferenciado de otras modalidades extrahoteleras más clásicas, principalmente los apartamentos turísticos, pero también en algunos casos de las viviendas vacacionales, ello a pesar de que en todas las modalidades se ofrece un servicio básico común: el destinado a un alojamiento temporal para estancias cortas. Dicho tratamiento deriva en gran medida de la modificación de la LAU, puesto que, mientras que considera que los arrendamientos de temporada sí tienen cabida en la propia ley, para «la cesión temporal de uso de la totalidad de una vivienda amueblada y equipada en condiciones de uso inmediato, comercializada o promocionada en canales de oferta turística o 
REALA. Nueva Época - N. 14, octubre 2020 - ISSN: 1989-8975 - DOI: https://doi.org/10.24965/reala.i14.10784 - [Págs. 180-200]

Elementos comunes y diferencias de la respuesta regulatoria a los retos del alojamiento colaborativo y el alquiler de corta duración...

por cualquier otro modo de comercialización o promoción, y realizada con finalidad lucrativa» abre la posibilidad de que se regulen a través de la normativa sectorial.

La respuesta a esta ambigüedad no es unánime en la normativa sectorial; así, las comunidades autónomas han ido asociando términos que en muchos casos pueden generar confusión (Guillén, 2018: 231), y las distinciones entre conceptos dentro de la misma categoría extrahotelera varían en gran medida. En casos como el andaluz, la distinción entre apartamentos y viviendas de uso turístico se justifica considerando que se trata de una actividad menos profesionalizada (con las consiguientes consecuencias fiscales). En la regulación de otras comunidades, no obstante, nos encontramos con que se considera una categoría de apartamento turístico que debe, además, regirse por unos requerimientos concretos, como así aparece en el Decreto 230/2011, de Navarra (si bien en este caso es cierto que se encuentran muy vinculados a los de los apartamentos turísticos):

«Artículo 3. Modalidad de Vivienda Turística. Podrán adscribirse a la modalidad de Vivienda Turística los apartamentos turísticos tipo casa, villa, chalet, cueva, construcciones prefabricadas o similares de carácter fijo y los adosados o las partes independientes de un edificio que cumplan con los siguientes requisitos mínimos:

a) Superficie útil mínima de $90 \mathrm{~m}^{2}$.

b) Acceso independiente.

c) Segregación vertical».

Las condiciones edificatorias o el hecho de que los inmuebles estén sometidos al régimen de propiedad horizontal son el elemento más común entre las diferentes comunidades autónomas a la hora de distinguir entre las modalidades de alojamientos extrahoteleros. Es más, uno de los requisitos más frecuentes para dicha diferenciación «se basa en que los apartamentos turísticos constituyen unidades complejas integradas en bloques o conjuntos cuya explotación se encuentra bajo un mismo titular y ofertan un número mínimo de unidades de alojamiento - determinado por la normativa autonómica-; en tanto que las viviendas de uso turístico se tratan de pisos, apartamentos o casas aisladas que no están sujetas a esas limitaciones» (del Busto et al., 2019: 66). Es decir, se hace hincapié en que se trate de unidades aisladas y no conjuntos, lo cual conecta con antecedentes normativos en España, en concreto con el Real Decreto 2877/1982, de 15 de octubre, donde ya podemos encontrar la utilización del concepto de viviendas turísticas vacacionales. En este mismo texto se hacía mención a la necesidad de una «adecuada regularización administrativa de numerosos alojamientos que estando actualmente en el mercado no reúnen las circunstancias que califican a los apartamentos turísticos». Aunque el contenido dado diste ya mucho de lo que se ha ido desarrollando entorno al alojamiento colaborativo, podemos ver un claro antecedente al tipo alojativo aquí estudiado, en especial por la poca confianza que se desprende (como veremos más adelante) sobre la calidad de las instalaciones ofrecidas.

El problema de esta distinción entre unidades aisladas y no conjuntos es que puede solaparse la regulación prevista para apartamentos y para viviendas turísticas en aquellos casos en los que un mismo propietario tiene diversas propiedades en un mismo edificio. Para evitar esta posible confusión, en el decreto andaluz, también el riojano, se determina el número máximo de viviendas con uso turístico que podrán ubicarse en un mismo edificio.

Solamente Extremadura no tiene una regulación específica diferenciada; puesto que Cantabria y Murcia aprobaron sus respectivas regulaciones a finales de 2019. Ello coincide con la regulación más antigua en este ámbito, pero también con una menor trayectoria turística en la región, que ha implicado poco desarrollo reglamentario hasta la actualidad.

Desde el punto de vista conceptual, podemos encontrar algunas divergencias por lo que respecta a la nomenclatura utilizada; encontramos «vivienda vacacional» en Islas Canarias, "vivienda con finalidad turística» en Andalucía o "estancias turísticas en viviendas» en Mallorca. A pesar de que no hay una visión unánime del fenómeno, y de que prima la pluralidad de conceptos utilizados, la noción «viviendas de uso turístico» es la más frecuente en la normativa sectorial. Este término aparece por primera vez en la Ley 18/2007 de 2 de diciembre, del derecho a la vivienda de la Comunidad Autónoma de Cataluña, y no resulta baladí que lo haga conectado al derecho a la vivienda, con la intención de «luchar contra la actividad empresarial y lucrativa de convertir ilegalmente las viviendas en alojamientos turísticos». De la misma manera, las distintas Comunidades Autónomas que optan por esta nomenclatura hacen énfasis en la noción de «vivienda». 
REALA. Nueva Época - N. 14, octubre 2020 - ISSN: 1989-8975 - DOI: https://doi.org/10.24965/reala.i14.10784 - [Págs. 180-200]

\section{LIMITACIONES URBANÍSTICAS}

En este apartado, nos referimos a aquellas restricciones que actúan sobre el territorio y las características de los inmuebles, y que por tanto pueden evitar la instalación de la propia actividad turística en viviendas. Resulta de especial relevancia observar qué cuestiones se regulan directamente en la normativa vigente, cuáles prevén un desarrollo posterior y qué papel juegan los municipios en dicho desarrollo.

\subsection{Tipología de edificación y ubicación dentro de las viviendas}

Es frecuente que las comunidades autónomas establezcan características edificatorias que las viviendas de uso turístico deben cumplir, en ocasiones, como ya se comentaba en el apartado anterior, porque ello delimita categorías distintas de alojamiento turístico no hotelero. En este sentido y como se explicaba previamente, la exigencia de que se trate de «edificaciones aisladas o con accesos independientes» frente a «conjuntos complejos» es uno de los elementos que con frecuencia se les exige a las viviendas turísticas frente a otras modalidades. Asimismo, en Aragón solo pueden ser considerados como tal «aquellos inmuebles sometidos al régimen de propiedad horizontal, viviendas unifamiliares aisladas $\mathrm{u}$ otras pertenecientes a complejos inmobiliarios privados [...]» (art. 2, Decreto 80/2015), pero no es el único caso, encontramos disposiciones similares en Asturias («viviendas independientes ubicadas en un edificio de varias plantas sometido a régimen de propiedad horizontal», art. 12), en Madrid (pisos, estudios, apartamentos o casas frente a unidades de alojamiento complejas, art. 2), por poner algunos ejemplos. Un caso curioso es el balear, que establece la prohibición explícita de usos turísticos en viviendas con infracciones de legalidad urbanística graves o muy graves (art. 50).

Mención aparte merece el caso canario, donde se impedía el establecimiento del modelo de «viviendas vacacionales» en aquellas edificaciones ubicadas en zonas turísticas o urbanizaciones (art. 3, Decreto 113/2015), aunque hasta la fecha los tribunales han considerado esta distinción un requisito desproporcionado y por tanto no ajustado a derecho (Sentencias de 21 de marzo y 25 de mayo de 2017, Sala de Instancia del Tribunal Superior de Canarias y Sentencia n. ${ }^{\circ}$ 25/2019, Sala 3..$^{\circ}$, del Tribunal Supremo). Ello se deduce, principalmente, de que esta restricción se introduce como «barrera a competidores que usan canales turísticos no convencionales» (Nogueira, 240: 2018), es decir, como una protección sectorial que en ningún caso puede entenderse como «interés general».

Las exigencias no siempre vienen determinadas por los decretos y leyes en cuestión, sino que pueden implicar meras referencias, con un papel singular otorgado a los ayuntamientos en la definición de los requisitos. Es en este sentido que el Decreto 101/2018, de 3 de julio, de viviendas y habitaciones de viviendas particulares para uso turístico del País Vasco, exige como requisito la comprobación de que la vivienda en cuestión «es conforme con la normativa municipal sobre edificación, con la indicación de si consta licencia de primera utilización o cédula de habitabilidad» y «si la actividad de alojamiento turístico que se propone es conforme con el uso urbanístico previsto por la normativa municipal y cumple las condiciones específicas que en su caso sean de aplicación» (art. 8.2 a y b).

Tanto Bilbao como San Sebastián se acogen a la posibilidad de establecer requisitos y limitaciones urbanísticas, que se concretan en la ubicación permitida (1. ${ }^{a}$ planta de edificios residenciales o plantas inferiores a viviendas en Bilbao (art. 6.3.23 a); mayor o menor permisibilidad en San Sebastián en función de la división zonal de usos (arts. 13-15), e incluso el tamaño del edificio o de la vivienda (San Sebastián). De la misma forma, también plantean restricciones Palma (solo viviendas unifamiliares) o Madrid (viviendas con accesos independientes).

\subsection{Comunidad de propietarios}

Como ha sido señalado de manera reiterada por asociaciones de vecinos, la mezcla de usos en un mismo inmueble genera problemas relacionados a los hábitos, aspiraciones y horarios dispares entre turistas y residentes. La principal herramienta de que disponen los propietarios en régimen de propiedad horizontal son los estatutos de la comunidad, a partir de los cuales pueden establecer los usos permitidos y prohibidos, las limitaciones del uso de los elementos privativos, y las cuotas de participación en los gastos comunes, entre otros. La mayoría de regulaciones, anteriores al Real Decreto-Ley $7 / 2019$, ya hacían mención a la comunidad de vecinos como actor con capacidad para limitar o prohibir la existencia de viviendas turísticas 
REALA. Nueva Época - N. 14, octubre 2020 - ISSN: 1989-8975 - DOI: https://doi.org/10.24965/reala.i14.10784 - [Págs. 180-200]

Elementos comunes y diferencias de la respuesta regulatoria a los retos del alojamiento colaborativo y el alquiler de corta duración...

Andrea Kruithof Ausina

en edificios afectados por el régimen de propiedad horizontal $(\mathrm{y}$, de hecho, como veíamos en anteriores apartados, limitan -como es el caso de Aragón- la posibilidad de establecer viviendas turísticas a aquellos inmuebles afectados por el régimen de propiedad horizontal).

Así lo expresa, por ejemplo, el Decreto 113/2015, de 22 de mayo, por el que se aprueba el Reglamento de las viviendas vacacionales de la Comunidad Autónoma de Canarias:

«Cuando se trate de viviendas sometidas al régimen de propiedad horizontal, solo podrán comercializarse como viviendas vacacionales aquellas en las que expresamente no se prohíba dicha actividad por los estatutos de la Comunidad de propietarios» (art. 12.2).

En estos casos, los propietarios o gestores de viviendas con finalidad turística deberán acreditar, junto con la declaración responsable, que esta actividad está permitida o no está expresamente prohibida por los estatutos de la comunidad de propietarios del inmueble en cuestión.

\subsection{Ubicación geográfica}

Por lo que respecta a la ubicación geográfica donde está permitido el establecimiento de esta tipología de alojamiento turístico, aproximadamente la mitad de las regiones hacen mención a algún tipo de limitación, a pesar de la oposición frontal de la CNMC, que considera carente de justificación cualquier restricción vía planeamiento urbanístico. Según la Comisión, en caso de que existiesen externalidades negativas, podrían corregirse con mecanismos más proporcionados (CNMC, 2018: 48-53).

Sin embargo, las autonomías que han establecido dichas restricciones se han ido ampliando, y entre las más interesantes destaca la previsión de espacios o zonas turísticas saturadas. Se trata de establecer situaciones posibles, relacionadas con la densidad de usos turísticos por zonas, que permitirían a las instituciones públicas restringir e incluso prohibir la concesión de nuevas licencias. En esta línea, Andalucía propone en su Ley de Turismo la identificación de espacios saturados o en peligro de estarlo para aplicar Programas de Recalificación de Destinos (art. 12.f, Ley 12/2011). También el caso valenciano es paradigmático en este sentido, reconociendo que un exceso turístico puede resultar lesivo para el buen funcionamiento urbano, inclusive el de sus servicios públicos, por lo que establece mecanismos de compensación económica para el «esfuerzo financiero d e los municipios turísticos, motivado por la actividad turística, en la prestación de servicios» (art. 24.4, Ley 15/2018). Estas previsiones suelen estar vinculadas al reconocimiento de determinados derechos ciudadanos, como el derecho subjetivo a la vivienda o al descanso, (art. 5.j, Ley 15/2018), pero también puede organizarse alrededor de criterios de protección medioambiental, como se expresa en la Ley de Turismo de Aragón (art. 19.2.b).

También Castilla-La Mancha, aunque con una referencia más genérica, propone la regulación medioambiental como posible elemento de ponderación a la hora de establecer máximos en los usos del espacio (art. 4, Decreto 36/2018), y no es poco frecuente la mención a la ordenación de usos del sector, con especial atención a la planificación ya existente en la normativa municipal. Así pues, en algunos casos la normativa autonómica dispone que han de ser los municipios quienes establezcan y desarrollen los límites en este ámbito. Si bien es cierto que la división zonal y los porcentajes máximos de usos (comerciales, residenciales, industriales) no son nuevos para los ayuntamientos, ya que se contemplaban en sus Planes Generales de Ordenación, la proliferación de estancias turísticas en viviendas ha contribuido a que algunas de estas entidades locales tomen medidas más restrictivas para contrarrestar los efectos sociales y económicos de este fenómeno.

Unas pocas ciudades (principalmente Barcelona, Palma, Madrid, Bilbao y San Sebastián) y dos islas (Formentera y Mallorca) han introducido sus propios modelos o particularidades regulatorias, con diseños similares. Mallorca y Formentera se limitan a establecer números máximos para plazas turísticas, pero lo más habitual es el diseño de zonificaciones, que incluyen diferentes niveles de permisividad en función de las áreas establecidas, previo estudio del nivel de concentración e incidencia de las viviendas turísticas. Como explica Arana, dado que «la regulación de la zonificación o calificación urbanística en normas territoriales y urbanísticas de carácter general es muy escasa», los ayuntamientos tienen mucha libertad para adaptar las medidas a su municipio (Arana, 2018: 12), tomando decisiones sobre en qué zonas puede permitirse la prestación de la actividad, llegando incluso a restricciones cuantitativas (número de plazas) o moratorias en algunos municipios o barrios (Boix, 2018: 275-276). 
MAPA 1. EJemplo de ZONIFICACIÓN: MALLORCA

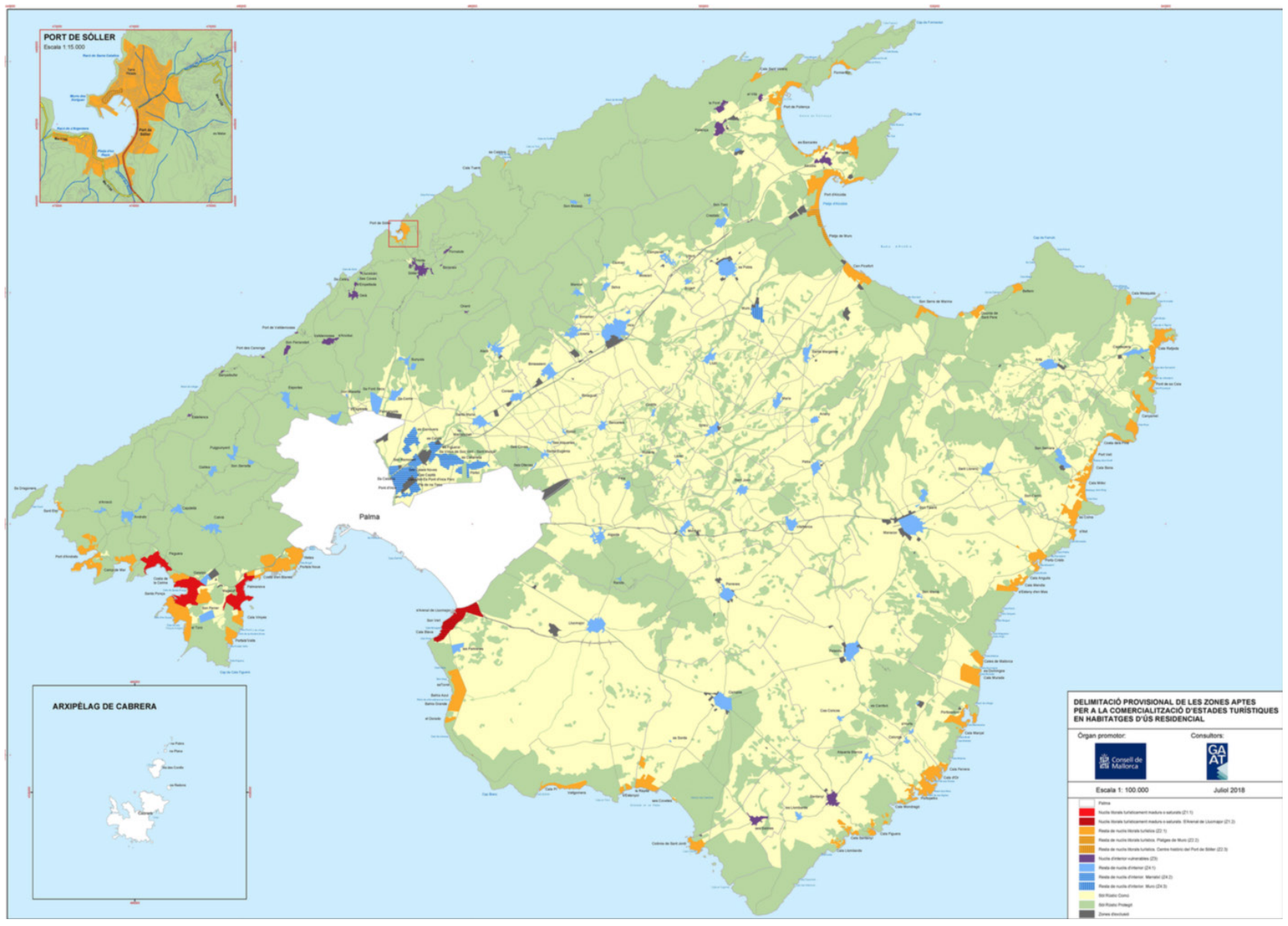

Fuente: CONSEJO INSULAR DE FORMENTERA (2018).

Ello suele coincidir con las zonas céntricas y más concurridas por el interés turístico y patrimonial de cada lugar, lo cual es de especial interés porque viene a demostrar el alcance distinto que un fenómeno puede tener en una misma ciudad. Así, el principio rector de estas medidas es «evitar la concentración excesiva de alojamientos turísticos a través de la distribución de los alojamientos turísticos en distintas zonas de la ciudad», como nos dice Artigot (2018: 167) para el caso de Barcelona. Como explica Román, con el PEUAT:

«se establecen una serie de áreas territoriales -denominadas Zonas Específicas- delimitadas conforme a su "sensibilidad" para acoger nuevas viviendas de uso turístico en atención a la intensidad de la oferta actual de alojamientos turísticos, la relación de plazas ofertadas respecto de la población residente, la saturación del espacio público y la morfología urbana o la especialización urbanística preponderante en la zona» (Román, 2018: 25).

Este plan, además, había previsto la reducción de plazas con el objetivo de «desturistificar» las zonas más saturadas; sin embargo, esta cuestión ha sido considerada nula de pleno derecho por el Tribunal Superior de Justicia Catalán (Sentencias n. ${ }^{\circ} 466,764,769$ y 765 del TSJC, Sala de lo Contencioso Administrativo).

\section{LIMITACIONES DE LA ACTIVIDAD}

Según Herrero (2017: 153), la respuesta normativa ante el fenómeno del alojamiento «colaborativo» se ha caracterizado por su foco en la relación entre arrendadores y huéspedes, más que en el papel que puedan jugar las plataformas mediadoras. En esta línea, se han venido aprobando en las respectivas comunidades autónomas disposiciones con el objetivo de limitar y establecer condiciones de diferente tipo para la 
REALA. Nueva Época - N. 14, octubre 2020 - ISSN: 1989-8975 - DOI: https://doi.org/10.24965/reala.i14.10784 - [Págs. 180-200]

Elementos comunes y diferencias de la respuesta regulatoria a los retos del alojamiento colaborativo y el alquiler de corta duración...

actividad turística en viviendas. Algunos autores (Herrero, 2017: 156; Doménech, 2015: 35-66) sugieren que, dichas exigencias, establecidas con la idea de preservar un nivel de calidad mínimo en los servicios, pueden ser excesivas, dado que, herederas del marco regulador preexistente (las condiciones establecidas para establecimientos turísticos en toda su variedad), no atienden a las innovaciones aportadas por las nuevas tecnologías, principalmente por lo que respecta a la existencia de sistemas de valoración de los establecimientos, lo que permite disminuir enormemente las asimetrías informativas entre usuarios y empresarios del sector. A pesar de estas consideraciones, la regulación autonómica se vuelca en la tutela de los intereses y derechos de los usuarios (Herrero, 2017: 156) a la vez que intenta garantizar su compatibilidad con el uso residencial, lo que se traduce en requerimientos mínimos que las viviendas tienen que cumplir en el desarrollo de su actividad: salud, seguridad, la calidad en el ejercicio de las prestaciones, características mínimas de las viviendas, derechos y deberes de los usuarios, entre otros.

Aunque la práctica totalidad de las regiones desarrolla disposiciones de este tipo, el nivel de detalle en las exigencias varía enormemente. Asimismo, como nos señala Boix (2018: 279-280), las nuevas normativas no inciden tanto en cuestiones relativas a la calidad del servicio, como se identifica en la regulación cántabra, cuyo interés es, principalmente, la generación de un marco de tramitación ágil. En cambio, muchas de ellas centran su atención en la ordenación territorial de la actividad.

\subsection{Requisitos técnicos mínimos}

Dentro de esta categoría se encuentran los requisitos relacionados con las condiciones de habitabilidad, es decir, aquellos elementos que aseguren unas condiciones mínimas de calidad y de confort a los usuarios.

En este ámbito, uno de los elementos más mencionados en las distintas regulaciones es la exigencia de un tamaño mínimo, tanto de la vivienda como la de sus estancias, en condiciones que sean equiparable a las exigidas para un uso residencial. Navarra, por ejemplo, establece requerimientos específicos sobre las dimensiones exigibles -una superficie útil mínima de $90 \mathrm{~m}^{2}$ - (art. 3.a, Decreto 230/2011), mientras que Islas Baleares establece que se debe disponer de como mínimo un baño por cada 4 plazas (art. 52.2, Ley 8/2012), por poner algunos ejemplos.

Además de los requisitos mencionados, otra de las características comunes entre las distintas comunidades autónomas está relacionada con los servicios y suministros mínimos que deben prestarse, entre los que se especifica con frecuencia el agua fría y caliente permanente, el suministro de gas y/o electricidad, también, en ocasiones, incluso la exigencia de climatización de las estancias que permita mantener una temperatura ambiental adecuada, o, como en Andalucía y Asturias, la obligatoriedad de ofrecer ventilación directa en las habitaciones y algún sistema de oscurecimiento de las ventanas (art. 6, Decreto 28/2016). Asimismo, también aparecen con relativa frecuencia los equipamientos y enseres exigibles, de manera que las viviendas estén suficientemente amuebladas y dotadas de los aparatos, muebles y electrodomésticos necesarios para su uso inmediato y con la finalidad de prestar un servicio acorde al número de plazas de que dispongan (art. 6, Decreto 28/2016 y art. 67.2, Decreto 159/2012, entre otros). Ello incluye no solo el mobiliario, sino también, para algunas regiones, la «cubertería, menaje, lencería y equipamientos inherentes a las mismas» (art. 13.2, Decreto 48/2016, de Asturias).

De especial relevancia es la imposición, aunque minoritaria en las normativas, de la insonorización de los apartamentos respecto de los colindantes, al igual que de toda la maquinaria, como elemento que haga más fácil la convivencia con los residentes. En el caso valenciano, el necesario aislamiento térmico y acústico viene determinado por el Decreto 92/2009, en vigor en todo lo que no se oponga a la nueva normativa (Gimeno, 2018).

Cabe remarcar que la pormenorización de estos estándares es muy variable entre regiones, y mientras que en algunos casos se opta por una mera referencia a normativa aplicable a viviendas, otras especifican con gran detalle las comodidades y elementos con los que debe contar cada inmueble. Entre los aspectos que suelen mencionarse de forma más genérica, son frecuentes las normativas sectoriales de accesibilidad y seguridad en los edificios; en segundo lugar, también pueden citarse regulaciones referentes a sanidad y medio ambiente (por ejemplo, en Madrid).

Como elemento distintivo, el Decreto 29/2019, de 9 de abril, del Consejo de Gobierno, por el que se modifica el Decreto 79/2014, de 10 de julio, por el que se regulan los Apartamentos Turísticos y las Viviendas de Uso Turístico de la Comunidad de Madrid, recoge que el inicio de la actividad turística en un inmueble estará sujeta a la comprobación de que los requisitos marcados se cumplen.

La aplicación de toda esta serie de requisitos ha sido cuestionada por algunos de los actores involucrados. De hecho, muchos de los artículos citados han sido recurridos ante los tribunales -entre ellos, 
REALA. Nueva Época - N. 14, octubre 2020 - ISSN: 1989-8975 - DOI: https://doi.org/10.24965/reala.i14.10784 - [Págs. 180-200]

Elementos comunes y diferencias de la respuesta regulatoria a los retos del alojamiento colaborativo y el alquiler de corta duración...

por la Abogacía del Estado-, a razón de su poca justificación y desproporcionalidad, suponiendo entonces una carga innecesaria, así como una vulneración de la libre empresa, y por tanto contrarios a la Directiva Europea 2006/123/CE y a la normativa española que la transpone. La jurisprudencia al respecto no es unánime: si bien los tribunales han considerado en varias ocasiones que dichas medidas benefician en último caso a los consumidores y son, en definitiva, garantía de la calidad del servicio (Sentencia $\mathrm{n}$. 1237/2019, del Tribunal Supremo, Sala $3 .^{\text {a }}$, y Sentencia n. ${ }^{\circ} 41 / 2017$, del Tribunal Superior de Canarias, Sala de lo Contencioso,), también se han considerado «excesivos» algunos de los requisitos, como la exigencia de climatización andaluza (Sentencia n. ${ }^{\circ}$ 1400/2019, del Tribunal Supremo, Sala de lo Contencioso-administrativo).

\subsection{Capacidad máxima}

Prácticamente todas las comunidades autónomas regulan la capacidad máxima que podrán alojar las viviendas. Como formulación más frecuente, ello viene determinado por lo establecido en la licencia de ocupación o la cédula de habitabilidad, mientras que en otras pocas normativas se establecen ratios por metro cuadrado. En este último caso, se encuentra la normativa de Aragón (art. 8, Decreto 80/2015).

Andalucía contempla una alternativa mixta, por la que «la capacidad máxima de éstas, vendrá limitada a lo dispuesto en la licencia de ocupación. En todo caso, cuando el uso de la vivienda sea completo no podrá ser superior a quince plazas y cuando el uso sea por habitaciones, no podrá superar las seis plazas, no pudiendo exceder en ambos tipos de cuatro plazas por habitación» (art. 5.2, Decreto 28/2016).

Independientemente de las fórmulas utilizadas, la normativa sectorial es taxativa respecto a la sobreocupación; incluso para aquellos casos (Extremadura, Cataluña, Comunidad Valenciana y Galicia) en los que se permite a los propietarios establecer sus límites, la sobrecontratación se encuentra penalizada.

\subsection{Mantenimiento y limpieza}

En esta categoría se hace referencia a cuestiones relativas al estado de conservación, mantenimiento e higiene de los inmuebles, con tal de asegurar «el adecuado estado de conservación de sus estructuras e instalaciones» (art. 6, Decreto 80/2015) que las viviendas de uso turístico se encuentran siempre en las debidas condiciones para su uso. A excepción de Extremadura, todas las regulaciones determinan requisitos en este ámbito, con una gran variación de pormenorización. Hasta cierto punto, estos requisitos «equiparan» la atención y el servició turístico en viviendas y en alojamiento hotelero, especificando la necesidad de recoger la basura, la frecuencia de la limpieza, así como de cambio de lencería.

\subsection{Tiempo permitido de alquiler}

Como veíamos con anterioridad, la Ley de Arrendamientos Urbanos utiliza la noción de temporalidad a la hora de identificar la cesión turística de la vivienda, sin que ello se concrete en un mínimo o máximo. Las comunidades autónomas regulan de forma muy distinta el tiempo de alquiler para las viviendas turísticas. Para el caso que aquí nos ocupa, no se han incluido aquellas determinaciones cuyo objetivo es evitar la posibilidad de que, como expresa Guillén «el turista/inquilino pueda establecer de manera indirecta su residencia habitual en dicha vivienda» (Guillén, 2018: 249). Se trata de aquellas comunidades que como Aragón limitan la cesión de la vivienda por usuario, pero que no contemplan tiempos máximos de uso turístico en inmuebles residenciales. El interés de hacer esta distinción reside en bien poder identificar si las limitaciones existentes se utilizan para categorizar el uso turístico intensivo (anual) frente al que no lo es (por ejemplo, de temporada) y por tanto una actividad con mayor o menor nivel de profesionalización; bien para evitar que los inmuebles se pongan a disposición de los turistas por un tiempo superior del que se considera deseable, sin que ambas interpretaciones sean incompatibles entre sí.

Es importante tener en cuenta, como nos recuerda Boix, que:

«en un territorio turístico como los de las zonas españolas de mayor demanda, habitualmente costeras, (...) es relativamente habitual que se empleen inmuebles propios en ciertas épocas del año para su alquiler turístico, lo que quizás explica algunos de los equilibrios de las normas autonómicas de esas zonas, reticentes a fijar umbrales cuantitativos o haciéndolo en un número de días más bien elevado (60-90 días)» (Boix, 2018: 277). 
REALA. Nueva Época - N. 14, octubre 2020 - ISSN: 1989-8975 - DOI: https://doi.org/10.24965/reala.i14.10784 - [Págs. 180-200]

Elementos comunes y diferencias de la respuesta regulatoria a los retos del alojamiento colaborativo y el alquiler de corta duración...

En ese sentido, solo 4 comunidades autónomas establecen umbrales de alquiler máximo. A diferencia de otras regiones, Galicia y Cataluña no se limitan a establecer el tiempo máximo consecutivo que se puede alquilar a un solo usuario, sino que regulan tiempo total de «cesión de uso continuado» de las viviendas. También lo hace la ciudad de Valencia, que limita el alquiler turístico de los inmuebles a 60 días en el centro de la ciudad.

En la normativa de la Comunidad Foral de Navarra el planteamiento es muy similar, si bien el límite se fija en los tres meses (art. 2.1, Decreto 230/2011). La regulación balear, por su parte, tiene sus particularidades a la hora de especificar los usos máximos que corresponden a cada modalidad (con mayor o menor nivel de restricción). Así, la exigencia temporal se aplica únicamente para la modalidad de alquiler de vivienda principal, para la cual es obligatorio el plazo máximo de alquiler de 60 días en el periodo de un año (art. 50.20, Ley 8/2012).

En el caso de los umbrales mínimos, establecen disposiciones al respecto La Rioja, Castilla y León y Castilla la Mancha. En estos casos, la intencionalidad es más sencilla de identificar, como demuestra el nuevo redactado del artículo 66.2 introducido por el Decreto 40/2018, de 23 de noviembre, por el que se modifica el Decreto 10/2017, de 17 de marzo, por el que se aprueba el Reglamento General de Turismo de La Rioja en desarrollo de la Ley 2/2001, de 31 de mayo, de Turismo de La Rioja:

«No tendrá la consideración de vivienda de uso turístico, aun cuando cumpla con los requisitos del apartado anterior, la vivienda que se destine al alquiler durante un único período consecutivo igual o inferior a tres meses al año independientemente de la efectiva ocupación en ese período».

La Comisión Nacional de los Mercados y la Competencia (CNMC) ha sido muy crítica respecto al establecimiento de umbrales de mínimos o máximos, alegando su posible efecto en la oferta y el consiguiente impacto en de términos de competencia y precios (CNMC, 2018: 43). De hecho, el precepto establecido por el Decreto 79/2014, según el cual las VUT no podían contratarse por un periodo inferior a cinco días fue recurrido por la Comisión a través del Abogado general, alegando «que infringía tanto el art. $38 \mathrm{CE}$, como la Directiva de Servicios comunitaria» (Guillén, 2018: 250). La prohibición prevista fue anulada por la Sentencia n. ${ }^{\circ} 302 / 2016$, de 2 de junio, del Tribunal Superior de Justicia de Madrid, coincidiendo con la CNMC en que no concurría en este caso una razón imperiosa de interés general, constituyendo entonces «una restricción injustificada y un obstáculo al mantenimiento de la competencia efectiva en el mercado entre los operadores turísticos en materia de alojamiento» (fundamento jurídico séptimo). Consecuentemente, en el decreto posterior de modificación (Decreto 29/2019) desaparece toda mención al tiempo mínimo de alquiler.

\subsection{Normas de convivencia}

Las normas de convivencia se prescriben como una garantía para la coexistencia entre pisos turísticos y viviendas y para evitar el desarrollo de actividades en las VUT que sean disruptivas para la comunidad de vecinos. Por norma general, hacen incidencia en la necesidad de respetar las convenciones de orden público e higiene, al amparo de lo establecido en el art. 7.2 de la Ley de Propiedad Horizontal. Estas normas suelen aparecer entre las obligaciones de las personas usuarias.

En algunos decretos se determina que el incumplimiento de dichas reglas será motivo de expulsión (art.12.2, Decreto 80/2015). Incluso, como en el caso de Asturias, para la expulsión de los infractores «podrán recabar el auxilio de las fuerzas de orden público» (art. 28.2, Decreto 48/2016).

\subsection{Cesión por estancias/alquiler por habitaciones}

Es poco habitual que se permita el alquiler por habitaciones, la mayoría de normativas señalan la necesidad de alquilar las unidades de forma integral. De hecho, tal y como establece de la Encarnación (De la Encarnación, 2016: 41) «es el primero de los requisitos que se establece por todas las Comunidades Autónomas». Ello se debe a una interpretación restrictiva del artículo 5 e) de la LAU, en el que se alude a «la cesión temporal de uso de la totalidad de una vivienda». Si bien este articulado no prohíbe expresamente la cesión por habitaciones, la mayoría de normativas han optado por excluir cualquier posibilidad. Ante la ambigüedad de la LAU son plausibles interpretaciones distintas; como bien explican Sánchez y García:

«algunos entienden que el supuesto quedaría excluido de la LAU y regido por las normas del

Código Civil, por no tratarse de un arrendamiento ni para uso como vivienda ni como para uso 
REALA. Nueva Época - N. 14, octubre 2020 - ISSN: 1989-8975 - DOI: https://doi.org/10.24965/reala.i14.10784 - [Págs. 180-200]

Elementos comunes y diferencias de la respuesta regulatoria a los retos del alojamiento colaborativo y el alquiler de corta duración...

distinto en tanto no recae sobre una edificación; para otros sería un arrendamiento sometido a la LAU pero, dentro de esta, al régimen de los arrendamientos para uso distinto» (Sánchez y García, 2018: 160-161).

Sin embargo, las normativas más nuevas, como las de Cantabria y Murcia, sí habilitan la opción del alquiler parcial. En Andalucía, ello implica requerimientos añadidos, como vemos a continuación:

«Artículo 3.- Normas específicas sobre el alojamiento en habitaciones de viviendas particulares para uso turístico.

$(\ldots)$

2. En el caso de cesión por habitaciones de viviendas particulares para uso turístico, solo una persona física podrá ser titular de la actividad alojativa.

En tal supuesto, la persona ha de estar empadronada y tener su residencia efectiva en la vivienda en la que desarrolle la actividad. Dicho requisito ha de mantenerse durante todo el tiempo de desarrollo de la actividad, hasta que comunique formalmente su cese (Decreto 101/2018)».

Aunque su exclusión no necesariamente implica prohibición (como es el caso en Rioja), el planteamiento autonómico es tendencialmente restrictivo. Por su parte, «la Comisión Nacional de los Mercados y de las Competencia se muestra claramente a favor de que las Comunidades Autónomas permitan estas cesiones de uso» (De la Encarnación, 2016: 45), de forma coincidente con la postura asumida hasta el momento por la jurisprudencia. De hecho, la Sala de lo Contencioso del Tribunal Superior de Justicia de Castilla y León estimó parcialmente el recurso de la CNMC (Sentencia n. ${ }^{\circ} 64 / 2018$, del Tribunal Superior de Justicia de Castilla y León, Sala de lo Contencioso), anulando así la prohibición de cesión por habitaciones de la vivienda de uso turístico, al considerar que dicha limitación al ejercicio de la actividad turística no se encuentra justificado por razones de interés general, ni de protección del consumidor o usuario turístico, ni su prohibición deriva del art. 5.e de la Ley de Arrendamientos Urbanos.

\subsection{Permiso de inicio de actividad}

La mayoría de comunidades autónomas permiten el establecimiento de autorizaciones y/o comunicaciones previas para el inicio de actividad, si bien muy pocas lo regulan como requisito previo. Ello implica que se da la opción a que se establezcan posteriormente, bien a través de la regulación autonómica o la municipal. La normativa catalana es pionera en el establecimiento de dichos requisitos: la Ley 18/2007, de 28 de diciembre, ya «permitía a los Ayuntamientos regular el procedimiento de comunicación previa de inicio de actividad para la obtención del título habilitante de la actividad. Es decir, para la obtención de la licencia turística» (Artigot, 2018: 158).

De manera similar, aunque con un establecimiento posterior, comunidades como Castilla y León (art. 7.1 o Galicia, art. 42.1) contemplan la posibilidad de establecer autorizaciones, cuya responsabilidad trasladan al ámbito local y/o sectorial. Por su parte, el País Vasco (art. 8.1) e Islas Baleares (art. 23) contemplan situaciones excepcionales en las que se podrá exigir un control previo antes de establecer la actividad turística en inmuebles. Mientras que la ley balear hace una referencia a este supuesto sin más concreción, en el decreto vasco se tasan aquellas situaciones en las que deberá requerirse informe previo y vinculante, cuya tramitación corresponderá a los ayuntamientos (Decreto 101/2018).

La evolución de este supuesto en la Comunidad de Madrid merece mención aparte. Así, el decreto de 2014 preveía la posibilidad de autorizaciones o licencias. Sin embargo, esta posibilidad desaparece en el decreto de 2019, puesto que, como se admite en el preámbulo, ello puede ser incompatible con la legislación europea. Como alternativa, el nuevo decreto establece un Certificado de Idoneidad para las Viviendas de Uso Turístico (CIVUT), orientado a la comprobación previa al inicio de actividad de que los inmuebles cumplen con todos los requisitos -razonables y proporcionados, se remarca- de funcionamiento establecidos. El preámbulo añade, además, «que la voluntad que se persigue con esta regulación es ajena a los condicionantes urbanísticos con los que suele vincularse y condicionarse esta actividad. Así, este decreto de modificación enfoca las viviendas desde una perspectiva turística, no urbanística, sin perjuicio de que los municipios establezcan, si así lo consideran, ulteriores controles en el ámbito de sus respectivas competencias», dejando de nuevo abierta la puerta a la regulación local. 
REALA. Nueva Época - N. 14, octubre 2020 - ISSN: 1989-8975 - DOI: https://doi.org/10.24965/reala.i14.10784 - [Págs. 180-200]

Elementos comunes y diferencias de la respuesta regulatoria a los retos del alojamiento colaborativo y el alquiler de corta duración...

El planteamiento canario difiere un poco a los anteriores (pero con similares resultados), al exigir autorización si se requiere cambio del uso del suelo (art. 32, Ley 2/2012). De igual manera lo regula, la Ley 5/2014, de 25 de julio, de Ordenación del Territorio, Urbanismo y Paisaje, de la Comunitat Valenciana, en su artículo 214. En este caso, como argumenta Gimeno (2018: 356), se debe discernir si «destinar una vivienda al uso turístico comporta un cambio de uso urbanístico (del residencial al terciario)» y por tanto se requiere o no una licencia. La interpretación que los tribunales hacen al respecto no es, hasta la fecha, uniforme, y podemos encontrar sentencias que se pronuncian en ambas direcciones ${ }^{1}$.

Desde la perspectiva municipal, todos los ayuntamientos que han desarrollado regulación específica -a excepción de Palma- exigen a las futuras VUT algún tipo de habilitación previa. En el caso de San Sebastián, por poner un ejemplo, es necesario que los propietarios registren una comunicación previa (art. 19.3 Ordenanza).

\section{REGISTRO AUTONÓMICO DE ACTIVIDAD}

Todas las comunidades autónomas regulan la obligatoriedad de inscribir las viviendas turísticas en el Registro. En algunos casos, como explica Soriano (2018: 330) respecto a la Comunidad Valenciana, la necesidad de comunicar el inicio de actividad puede suponer una herramienta de control añadida, ya que como pasa en esta comunidad, las viviendas deberán ser clasificadas para poder operar, con lo que deberán cumplir con algunos de los requisitos establecidos para las distintas. Esta medida ha sido muy criticada por parte de la Comisión para la Defensa de la Competencia de la Comunidad Valenciana, que lo considera una vulneración a la libre competencia, que, además, «implica un exceso de trámites administrativos, que pueden suponer una carga excesiva y desincentivar la entrada de viviendas de turístico en el mercado de alojamiento.» (CNMC, 2018: 42). La jurisprudencia emitida al respecto (Sentencia n. ${ }^{\circ}$ 1741/2018, de 10 de diciembre, del Tribunal Supremo, Sala del Contencioso-Administrativo) coincide con este juicio, insistiendo en que la inscripción en el Registro no puede ser un condicionante para la actividad turística en viviendas puesto que sería una exigencia irrazonable (Fundamento Jurídico cuarto).

Sin embargo, el registro constituye un recurso muy importante para las instituciones a la hora de conseguir información, y su escasez un reto tanto para la regulación de la economía como para su investigación (Artigot, 2018: 152).

\section{CONCLUSIONES}

El uso del alojamiento privado para el turismo no es un fenómeno novedoso. No obstante, la incorporación de nuevas tecnologías, con una participación cada vez más directa de los usuarios y la aparición de las plataformas como entidades mediadoras en los servicios ha revolucionado la dimensión de su incidencia, facilitando la multiplicación de la oferta turística y la afluencia masiva de nuevos usuarios. La intensidad de estos usos, así como su potencial para generar problemas y costes sociales, ha sido reconocido por las distintas instancias de justicia como elementos que facultan a las distintas regiones para desarrollar un mayor control sobre las actividades, sin que ello entre en conflicto con la libre competencia y la regulación europea al respecto.

Las reacciones normativas a este fenómeno han tendido a encontrar caminos convergentes, y, en definitiva, han seguido una trayectoria similar a la vivida en el escenario europeo, que ha pasado desde «la permisión casi completa a la regulación más estricta, pasando por su prohibición en alguna capital» (De la Encarnación, 2018: 191). Ello se ha traducido, principalmente, en exigencias en dos grandes bloques. En primer lugar, por lo que respecta a las limitaciones urbanísticas, a partir de las cuales las entidades públicas determinan en qué espacios y edificios puede habilitarse la actividad, ya sea por consideraciones medioambientales o sociales y/o de convivencia. En segundo lugar, las limitaciones de actividad, dirigidas a preservar la calidad del servicio y buscar una cierta homologación con la regulación exigida a establecimientos

1 Así, mientras que la Sentencia n. ${ }^{\circ}$ 513/2013 del Tribunal Superior de Justicia de Madrid de 17 de abril de 2013 o la Sentencia n. ${ }^{\circ}$ 244/2016, del Juzgado de lo Contencioso Administrativo 1 de Donostia/San Sebastián, de 5 de diciembre de 2016, tienen una postura favorable a exigir licencia, no es del mismo parecer el Juzgado de lo Contencioso-Administrativo 6 de Valencia, que en su Sentencia n. ${ }^{\circ}$ 148/2016 sostiene que «del inicio de esta actividad no se deriva un cambio de uso urbanístico» (GIMENO, 2018: 357). 
hoteleros, a partir de requisitos de tipo técnico (mobiliario y equipamiento, medidas de seguridad, espacios mínimos), pero también exigiendo el cumplimiento de normas de convivencia, entre otros.

Aun así, dado que el impacto de las viviendas turísticas no es homogéneo, no necesariamente debería serlo la respuesta dada desde las instituciones. Ello es más evidente en el nivel local, por lo que respecta al planeamiento urbanístico en las ciudades, con el caso concreto de las zonificaciones que distinguen áreas con mayor o menor restricción en función de la incidencia y/o saturación de oferta, identificada previamente. Como nos advierte Nogueira, la crítica a una mayor homogeneización de las distintas normativas autonómicas y locales «en el fondo es deudora de una visión que no toma en consideración que la diversidad competencial ampara una variedad de preferencias regulatorias y políticas para abordar un mismo campo 0 adaptarse a circunstancias diversas» (Nogueira, 2018: 236).

En esta misma línea, convendría reflexionar al respecto de si «se quiere regular la actividad de forma global, como si siempre tuviera los mismos perfiles y planteara idénticos problemas, o por el contrario si se entiende más apropiado diferenciar entre situaciones que puedan tener perfiles suficientemente diferenciados» (Boix, 2018: 276). Así, por ejemplo, la negativa a permitir la cesión por habitaciones de las viviendas, plantea dudas -ya expresadas por los tribunales y por la CNMC- por equipararlo al alquiler de un inmueble en su totalidad, sin contemplar que pueda responder a un modelo diferenciado. Asimismo, también es importante señalar la disparidad de pareceres de los distintos actores en este proceso de definición, con una CNMC especialmente beligerante en su defensa por la libre competencia, frente a los ensayos de regulación autonómica y local.

En cualquier caso, es importante remarcar que la regulación sobre viviendas turísticas se encuentra en un momento de evolución, marcado por las primeras experiencias de éxito y fracaso de la variedad de enfoques, tanto dentro como fuera de España. Por ello, será necesario vislumbrar qué cuestiones reguladas no pasan la prueba de la aplicación práctica, es decir, qué costes de implementación y seguimiento implican y cuál es su nivel de efectividad. Medidas como los umbrales máximos de alquiler turístico ya han sido cuestionadas en estos términos, no obstante, faltan todavía análisis integrales sobre la aplicación de la normativa de viviendas turísticas que permitan avanzar en su mejor regulación, y que merecen atención específica en futuras monografías. 
REALA. Nueva Época - N. 14, octubre 2020 - ISSN: 1989-8975 - DOI: https://doi.org/10.24965/reala.i14.10784 - [Págs. 180-200]

Elementos comunes y diferencias de la respuesta regulatoria a los retos del alojamiento colaborativo y el alquiler de corta duración...

Andrea Kruithof Ausina

\section{ANEXO I. TABLA RESUMEN DE REGULACIONES AUTONÓMICAS Y MUNICIPALES}

\begin{tabular}{|c|c|c|c|c|c|}
\hline & $\begin{array}{l}\text { Regulación } \\
\text { específica }\end{array}$ & Limitaciones urbanísticas & $\begin{array}{l}\text { Limitaciones } \\
\text { actividad }\end{array}$ & Inscripción & Regulación \\
\hline NAVARRA & $\begin{array}{l}\text { Sí } \\
\text { Vivienda } \\
\text { turística }\end{array}$ & $\begin{array}{l}\text { Sí } \\
\text { • Tipología de edificio (art. 3). }\end{array}$ & $\begin{array}{l}\text { - Requisitos técnicos mínimos } \\
\text { (arts. 3, 19, 27-32c). } \\
\text { - Seguridad (arts. 19, 24). } \\
\text { - Mantenimiento (arts. 19, 20). } \\
\text { - Capacidad máxima (art. 26). } \\
\text { - Exclusión de cesión parcial } \\
\text { (art. 2.b). } \\
\text { - Tiempo de alquiler máximo (art. 2). }\end{array}$ & $\begin{array}{c}\text { Sí } \\
\text { (art. 9) }\end{array}$ & $\begin{array}{l}\text { Decreto foral 230/2011, } \\
\text { de } 26 \text { de octubre, por } \\
\text { el que se aprueba } \\
\text { el reglamento de } \\
\text { ordenación de los } \\
\text { apartamentos turísticos } \\
\text { en la comunidad foral de } \\
\text { Navarra. }\end{array}$ \\
\hline $\begin{array}{l}\text { COMUNIDAD } \\
\text { DE MADRID }\end{array}$ & $\begin{array}{c}\text { Sí } \\
\text { Viviendas } \\
\text { de uso turístico }\end{array}$ & $\begin{array}{l}\text { Sí } \\
\text { - Tipología de edificio (art. 2). } \\
\text { - Comunidad de vecinos } \\
\text { (art. 17.5, ref. Ley 49/1960). }\end{array}$ & $\begin{array}{l}\text { - Requisitos técnicos mínimos } \\
\text { (arts. 5, 17, 18). } \\
\text { - Seguridad (arts. } 5 \text { y 17). } \\
\text { - Mantenimiento (art. 5). } \\
\text { - Capacidad máxima (art. 18.4). } \\
\text { - Exclusividad del uso turístico } \\
\text { (art. 6). } \\
\text { - Autorización previa -certificado de } \\
\text { idoneidad- (art. 17). } \\
\text { - Exclusión de la cesión parcial } \\
\text { (art. 2.2). } \\
\text { - Usos de convivencia } \\
\text { (art. 5, ref. Ley 1/1999). }\end{array}$ & $\begin{array}{c}\text { Sí } \\
\text { (art. 11) }\end{array}$ & $\begin{array}{l}\text { Decreto 79/2014, } \\
\text { de } 10 \text { de julio, por el } \\
\text { que se regulan los } \\
\text { apartamentos turísticos } \\
\text { y las viviendas de } \\
\text { uso turístico de la } \\
\text { Comunidad de Madrid. } \\
\text { Decreto } 29 / 2019 \text {, de } 9 \\
\text { de abril, del Consejo de } \\
\text { Gobierno, por el que } \\
\text { se modifica el Decreto } \\
79 / 2014, \text { de } 10 \text { de julio. } \\
\text { Ley } 1 / 1999 .\end{array}$ \\
\hline MADRID & $\begin{array}{c}\text { Plan Especial } \\
\text { para la } \\
\text { regulación de } \\
\text { uso terciario } \\
\text { en su clase de } \\
\text { Hospedaje }(P E H)\end{array}$ & $\begin{array}{l}\text { Limitaciones por distritos } \\
\text { organizados en tres anillos } \\
\text { concéntricos - más restrictivos } \\
\text { cuanto más al centro- } \\
\text { (art. 6, PEH). } \\
\text { - Tipología de vivienda: accesos } \\
\text { independientes, tipología de } \\
\text { uso del suelo (art. 7.6.3 PGOU, } \\
\text { art. 7.1.4). } \\
\text { - Impacto acústico } \\
\text { (art. 5.3.5 PGOU). }\end{array}$ & $\begin{array}{l}\text { - Permiso de cambio de uso del } \\
\text { suelo en zonas residenciales } \\
\text { (art. 6, remite al Título } 5 \text { del } \\
\text { PGOU). } \\
\text { - Planes Especiales de Control } \\
\text { Urbanístico-Ambiental de Usos } \\
\text { (art. 8, PEH). } \\
\text { - Se requiere licencia (art. } 2.1 .1 \\
\text { PGOU; acuerdo de } 21 \text { mayo } \\
\text { CSPG). } \\
\text { - Tiempo de alquiler mínimo para } \\
\text { considerar vivienda turística: }+ \\
\text { de } 90 \text { días al año (uso comercial } \\
\text { según Acuerdo de } 21 \text { mayo CSPG). }\end{array}$ & Sí & $\begin{array}{l}\text { Plan General de } \\
\text { Ordenación Urbana de } \\
\text { Madrid (PGOU). } \\
\text { Ordenanza Especial de } \\
\text { Tramitación de Licencias } \\
\text { y Control Urbanístico. } \\
\text { Acuerdo de } 21 \text { de mayo } \\
\text { de } 2019 \text { de la Comisión } \\
\text { de Seguimiento del Plan } \\
\text { General de Ordenación } \\
\text { Urbana de Madrid de } \\
1997 \text { (PGOUM), tema } \\
\text { n. }{ }^{\circ} 363 .\end{array}$ \\
\hline $\begin{array}{l}\text { ISLAS } \\
\text { CANARIAS }\end{array}$ & $\begin{array}{c}\text { Sí } \\
\text { Viviendas } \\
\text { vacacionales }\end{array}$ & $\begin{array}{l}\text { Decreto 113/2015: } \\
\text { - Comunidad de propietarios } \\
\text { (art. 12.2, ref. a la Ley de } \\
\text { propiedad horizontal, } \\
\text { Decreto 113/2015). } \\
\text { - Ubicación (suelo residencial) } \\
\text { (art. 3.2, ref. a Ley 2/2013). } \\
\text { - Normativa urbanística } \\
\text { (ref. genérica a normativa } \\
\text { sectorial, art. 4). }\end{array}$ & $\begin{array}{l}\text { Decreto 113/2015: } \\
\text { - Requisitos técnicos mínimos } \\
\text { (art. 9, ref. al Decreto 117/2006, } \\
\text { art. 10). } \\
\text { - Capacidad máxima (art. 5.1). } \\
\text { - Seguridad (ref. genérica a } \\
\text { normativa sectorial, arts. } 4 \text { y 9) y } \\
\text { accesibilidad (ref. genérica, art. 4). } \\
\text { Mantenimiento (art. 4, art. 8). } \\
\text { - Exclusión de la cesión parcial } \\
\text { (art. 2.a) y 12.1). } \\
\text { - Usos de convivencia } \\
\text { (art. 5.2.b) y c)). } \\
\text { - Informe técnico turístico } \\
\text { (art. 34, Ley 2/2012). } \\
\text { - Permiso de cambio de uso del } \\
\text { suelo (art. 32, Ley 2/2012). }\end{array}$ & $\begin{array}{c}\text { Sí } \\
\text { (art. 12,3 } \\
\text { Decreto } \\
\text { 113/2015) }\end{array}$ & $\begin{array}{l}\text { Decreto } 113 / 2015, \text { de } 22 \\
\text { de mayo, por el que se } \\
\text { aprueba el Reglamento } \\
\text { de las viviendas } \\
\text { vacacionales de la } \\
\text { Comunidad Autónoma } \\
\text { de Canarias. } \\
\text { Ley de ordenación del } \\
\text { turismo de Canarias } \\
\text { L7/1995. } \\
\text { Decreto } 117 / 2006, \text { de } 1 \\
\text { de agosto, por el que se } \\
\text { regulan las condiciones } \\
\text { de habitabilidad de las } \\
\text { viviendas. } \\
\text { Ley } 2 / 2013, \text { de } 29 \text { de } \\
\text { mayo, de renovación y } \\
\text { modernización turística } \\
\text { de Canarias. }\end{array}$ \\
\hline
\end{tabular}


REALA. Nueva Época - N. ${ }^{014}$, octubre 2020 - ISSN: 1989-8975 - DOI: https://doi.org/10.24965/reala.i14.10784 - [Págs. 180-200]

Elementos comunes y diferencias de la respuesta regulatoria a los retos del alojamiento colaborativo y el alquiler de corta duración...

Andrea Kruithof Ausina

\begin{tabular}{|c|c|c|c|c|c|}
\hline & $\begin{array}{l}\text { Regulación } \\
\text { específica }\end{array}$ & Limitaciones urbanísticas & $\begin{array}{l}\text { Limitaciones } \\
\text { actividad }\end{array}$ & Inscripción & Regulación \\
\hline MURCIA & $\begin{array}{c}\text { Sí } \\
\text { Viviendas } \\
\text { de uso } \\
\text { turístico }\end{array}$ & No & $\begin{array}{l}\text { - Requisitos técnicos mínimos } \\
\text { (arts. 11-18) Mantenimiento } \\
\text { (art. 10). } \\
\text { - Capacidad máxima (art. 14). } \\
\text { - Permite el alquiler por habitaciones } \\
\text { (art. 2.b). } \\
\text { Mantenimiento (art. 10). }\end{array}$ & $\begin{array}{c}\text { Sí } \\
\text { (art. 28.3) }\end{array}$ & $\begin{array}{l}\text { Decreto } n .^{\circ} 256 / 2019, \\
\text { de } 10 \text { de octubre, } \\
\text { por el que se regulan } \\
\text { las viviendas de uso } \\
\text { turístico en la Región de } \\
\text { Murcia. }\end{array}$ \\
\hline LA RIOJA & $\begin{array}{c}\text { Sí } \\
\text { Viviendas } \\
\text { de uso } \\
\text { turístico }\end{array}$ & $\begin{array}{l}\text { - Comunidad de propietarios } \\
\text { (art. 67). } \\
\text { - Normativa municipal (art. 67). } \\
\text { - Tipología del edificio (art. 66.1). }\end{array}$ & $\begin{array}{l}\text { - Capacidad (art. 66.6, introducido } \\
\text { por el Decreto 40/2018). } \\
\text { - Requisitos técnicos mínimos } \\
\text { (art. 8, art. 66, ref. también al } \\
\text { Decreto 28/2013). } \\
\text { - Usos de convivencia (art. 20). } \\
\text { - Mantenimiento (art. 4). } \\
\text { - Tiempo de alquiler mínimo } \\
\text { (art. 66.b)). } \\
\text { - Exclusión de la cesión parcial -no } \\
\text { la prohíbe, pero no se considera } \\
\text { vivienda turística- (art. 66.1). } \\
\text { - Efectos mediodioambientales } \\
\text { (art. 3, ref. genérica a normativa } \\
\text { sectorial). } \\
\text { - Exclusión de viviendas habituales } \\
\text { (art. 66.2.a)). }\end{array}$ & \begin{tabular}{|l} 
Sí \\
Registro \\
de \\
proveedores \\
(art. 10.2)
\end{tabular} & $\begin{array}{l}\text { Decreto 40/2018, de } \\
23 \text { de noviembre, por } \\
\text { el que se modifica el } \\
\text { Decreto } 10 / 2017, \text { de } 17 \\
\text { de marzo, por el que se } \\
\text { aprueba el Reglamento } \\
\text { General de Turismo de } \\
\text { La Rioja en desarrollo } \\
\text { de la Ley } 2 / 2001 \text {, de } 31 \\
\text { de mayo, de Turismo de } \\
\text { La Rioja. } \\
\text { Decreto 10/2017, de } 17 \\
\text { de marzo, por el que se } \\
\text { aprueba el Reglamento } \\
\text { General de Turismo de } \\
\text { la Rioja en desarrollo de } \\
\text { la Ley } 2 / 2001, \text { de } 31 \text { de } \\
\text { mayo, de Turismo de la } \\
\text { Rioja. } \\
\text { Decreto } 28 / 2013, \text { de } \\
13 \text { de septiembre, por } \\
\text { el que se regulan las } \\
\text { condiciones mínimas } \\
\text { de habitabilidad de } \\
\text { las viviendas en la } \\
\text { Comunidad Autónoma } \\
\text { de La Rioja. }\end{array}$ \\
\hline $\begin{array}{l}\text { CASTILLA- } \\
\text { LA MANCHA }\end{array}$ & $\begin{array}{c}\text { Sí } \\
\text { Viviendas } \\
\text { de uso } \\
\text { turístico }\end{array}$ & $\begin{array}{l}\text { Sí } \\
\text { - Comunidad de propietarios } \\
\text { (art. 4, 16.b)). } \\
\text { - Regulación medioambiental } \\
\text { y urbanística (art. 4, ref. a } \\
\text { normativa sectorial). }\end{array}$ & $\begin{array}{l}\text { - Exclusión de la cesión parcial } \\
\text { (art. 2.c)). } \\
\text { - Exclusividad del uso (art. 3). } \\
\text { - Requisitos técnicos mínimos } \\
\text { (art. 4, ref. genérica a la normativa } \\
\text { sectorial, arts. 16.1 y 16.2). } \\
\text { - Capacidad máxima (art. 16.3). } \\
\text { - Mantenimiento (art. 16.g)). } \\
\text { - Seguridad (art. 16.a), ref. genérica } \\
\text { a la normativa sectorial). } \\
\text { - Accesibilidad (art. 4, ref. genérica). }\end{array}$ & $\begin{array}{c}\text { Sí } \\
\text { (art. 6.6) }\end{array}$ & $\begin{array}{l}\text { Decreto } 36 / 2018 \text {, de } 29 \\
\text { de mayo, por el que se } \\
\text { establece la ordenación } \\
\text { de los apartamentos } \\
\text { turísticos y las viviendas } \\
\text { de uso turístico en } \\
\text { Castilla-La Mancha. }\end{array}$ \\
\hline CATALUÑA & $\begin{array}{c}\text { Sí } \\
\text { Viviendas } \\
\text { de uso } \\
\text { turístico }\end{array}$ & $\begin{array}{l}\text { Decreto 159/2012: } \\
\text { - Ordenación de usos del sector } \\
\text { (art. 68.6). } \\
\text { - Estatutos de la comunidad } \\
\text { de propietarios (art. 68.6). }\end{array}$ & $\begin{array}{l}\text { Decreto 159/2012: } \\
\text { - Exclusión de la cesión parcial } \\
\text { (art. 66.2). } \\
\text { - Requerimientos técnicos mínimos } \\
\text { (art. 67). } \\
\text { - Condiciones y mantenimiento } \\
\text { (art. 67). } \\
\text { - Tiempo de alquiler máximo } \\
\text { (art. 66.3). } \\
\text { - Usos de convivencia (art. 68.11). }\end{array}$ & $\begin{array}{c}\text { Sí } \\
\text { (art. 68.8, } \\
\text { Decreto } \\
\text { 159/2012) }\end{array}$ & $\begin{array}{l}\text { Decret 159/2012, } \\
\text { de } 20 \text { de novembre, } \\
\text { d'establiments } \\
\text { d'allotjament turístic i } \\
\text { d'habitatges d'ús turístic. } \\
\text { Llei } 13 / 2002 \text {, de } 21 \\
\text { de juny, de turisme de } \\
\text { Catalunya. }\end{array}$ \\
\hline
\end{tabular}


REALA. Nueva Época - N. ${ }^{014}$, octubre 2020 - ISSN: 1989-8975 - DOI: https://doi.org/10.24965/reala.i14.10784 - [Págs. 180-200]

Elementos comunes y diferencias de la respuesta regulatoria a los retos del alojamiento colaborativo y el alquiler de corta duración...

Andrea Kruithof Ausina

\begin{tabular}{|c|c|c|c|c|c|}
\hline & $\begin{array}{l}\text { Regulación } \\
\text { específica }\end{array}$ & Limitaciones urbanísticas & $\begin{array}{l}\text { Limitaciones } \\
\text { actividad }\end{array}$ & Inscripción & Regulación \\
\hline BARCELONA & $\begin{array}{l}\text { Sí } \\
\text { Pla Especial } \\
\text { Urbanístic } \\
\text { 'Allotjaments } \\
\text { Turístics. } \\
\text { *Suspendido } \\
\text { por distintas } \\
\text { sentencias }\end{array}$ & $\begin{array}{l}\text { - Ubicación (no se pueden } \\
\text { establecer en bajos). } \\
\text { - División y regulación más o } \\
\text { menos restrictiva en función } \\
\text { de zonas (prohibición en zona } \\
1 \text {, antenimiento del número } \\
\text { total en zona } 2 \text {, zona } 3 \text { en } \\
\text { función de densidad máxima de } \\
\text { plazas y zona } 4 \text { con regulación } \\
\text { particular) (art. 23). } \\
\text { - Usos del suelo -Prohibición } \\
\text { de cambio de uso en lugares } \\
\text { destinados a vivienda antes de } \\
\text { 2015- (art. 9.a)); uso exclusivo } \\
\text { para el edificio entero (art. 9.b)). }\end{array}$ & $\begin{array}{l}\text { - Referencia genérica a la normativa } \\
\text { sectorial, ordenanzas y al Decreto } \\
\text { 159/2012 (art. 22.1.a)). } \\
\text { - Necesidad de licencia urbanística } \\
\text { y autorización para casos } \\
\text { determinados (art. 9.d). } \\
\text { - Imposibilidad de establecer en } \\
\text { vivienda principal en Ciutat Vella } \\
\text { (Disposición Addicional Primera). }\end{array}$ & $\begin{array}{c}\text { Sí } \\
\text { (art. 24) }\end{array}$ & PGOU de Barcelona. \\
\hline ANDALUCÍA & $\begin{array}{c}\text { Sí } \\
\text { Viviendas } \\
\text { con finalidad } \\
\text { turística }\end{array}$ & $\begin{array}{l}\text { - Plan General de Turismo: } \\
\text { Espacios turísticamente } \\
\text { saturados (art. 12.f), Ley } \\
\text { 12/2011). Prevé programas } \\
\text { de Recalificación de Destinos. } \\
\text { - Uso del suelo (art. } 3 \text { Decreto } \\
\text { 28/2016). } \\
\text { - Ubicación: solo zonas urbanas } \\
\text { (art. 1.2.c), Decreto 28/2016). }\end{array}$ & $\begin{array}{l}\text { Decreto 28/2016: } \\
\text { - Convivencia (art. 2.5). } \\
\text { - Capacidad máxima (art. 5.2). } \\
\text { - Requerimientos técnicos mínimos } \\
\text { (art. 2, ref. genérica a normativa } \\
\text { sectorial, art. 6). } \\
\text { - Mantenimiento (art. 6.h)). } \\
\text { - Tiempo de alquiler máximo } \\
\text { (art. 1.2.b)). } \\
\text { - Número de viviendas de un mismo } \\
\text { propietario (art. 1.2.d)). } \\
\text { - Permitida cesión parcial (art. 5). }\end{array}$ & $\begin{array}{c}\text { Sí } \\
\text { (art. 9.3) }\end{array}$ & $\begin{array}{l}\text { Decreto } 28 / 2016 \text {, } \\
\text { de } 2 \text { de febrero, de } \\
\text { las viviendas con } \\
\text { fines turísticos y de } \\
\text { modificación del } \\
\text { Decreto } 194 / 2010, \\
\text { de } 20 \text { de abril, de } \\
\text { establecimientos de } \\
\text { apartamentos turísticos. } \\
\text { Ley } 12 / 2011 \text {, de } 23 \text { de } \\
\text { diciembre, del Turismo } \\
\text { de Andalucía. }\end{array}$ \\
\hline ASTURIAS & $\begin{array}{l}\text { Sí } \\
\text { Viviendas } \\
\text { de uso } \\
\text { turístico }\end{array}$ & $\begin{array}{l}\text { Sí } \\
\text { (Decreto 48/2016) } \\
\text { - Tipología de edificio (art. 12). } \\
\text { - Posible prohibición en } \\
\text { ordenación urbanística o } \\
\text { comunidad de vecinos } \\
\text { (art. } 12 \text { y 27.b)). } \\
\text { - Zonas turísticas saturadas } \\
\text { (Ley 7/2001). }\end{array}$ & $\begin{array}{l}\text { Decreto 48/2016: } \\
\text { - Requerimientos técnicos mínimos } \\
\text { (art. 13, art. 22). } \\
\text { - Mantenimiento (art. 13.b), art. 24). } \\
\text { - Convivencia y orden público } \\
\text { (art. } 16 \text { y art. 28.e)). } \\
\text { - Capacidad máxima (art. 13.f). } \\
\text { - Ordenanzas municipales (art. 27.a). } \\
\text { - Permitida la cesión parcial } \\
\text { (art. 12.1). }\end{array}$ & $\begin{array}{c}\text { Sí } \\
\text { (art. 31) }\end{array}$ & $\begin{array}{l}\text { Decreto } 48 / 2016 \text {, de } 10 \\
\text { de agosto, de viviendas } \\
\text { vacacionales y viviendas } \\
\text { de uso turístico. } \\
\text { Ley } 7 / 2001 \text {, de } 22 \text { de } \\
\text { junio, de Turismo. }\end{array}$ \\
\hline ARAGÓN & $\begin{array}{l}\text { Sí } \\
\text { Viviendas } \\
\text { de uso } \\
\text { turístico }\end{array}$ & $\begin{array}{l}\text { Decreto 80/2015: } \\
\text { - Tipología de edificio (art. 2.a), } \\
\text { art. 4.2). } \\
\text { - Comunidad de propietarios } \\
\text { (art. 14.2.f). } \\
\text { - Número de viviendas en } \\
\text { un mismo edificio/conjunto } \\
\text { (art. 4.2.b). } \\
\text { - Zonas turísticas saturadas } \\
\text { (art. 19, Ley de Turismo). }\end{array}$ & $\begin{array}{l}\text { Decreto 80/2015. } \\
\text { - Requerimientos técnicos mínimos } \\
\text { (art. 2.a, art. 6, art. 7, art. 9). } \\
\text { - Cesión integral (art. 3). } \\
\text { - Seguridad (art. 6). } \\
\text { - Capacidad máxima (art. 8). } \\
\text { - Habitabilidad y mantenimiento } \\
\text { (art. 2.a), art. 6, art. 9, art. 10). } \\
\text { - Higiene y orden público (art. 2.c), } \\
\text { art. 16, art. } 5 \text { refiere a la Ley 2013, } \\
\text { art. 22.c)). }\end{array}$ & $\begin{array}{l}\text { Sí } \\
\text { (art. 14.4, } \\
\text { art. 15, } \\
\text { art. } 28 \\
\text { en la } \\
\text { Ley de } \\
\text { Turismo) }\end{array}$ & $\begin{array}{l}\text { Decreto } 80 / 2015, \text { de } 5 \\
\text { de mayo, del Gobierno } \\
\text { de Aragón, por el que } \\
\text { aprueba el reglamento } \\
\text { de las viviendas de uso } \\
\text { turístico en Aragón. } \\
\text { Decreto Legislativo } \\
1 / 2016, \text { de } 26 \text { de julio, } \\
\text { del Gobierno de Aragón, } \\
\text { por el que se aprueba el } \\
\text { texto refundido de la Ley } \\
\text { del Turismo de Aragón. }\end{array}$ \\
\hline CANTABRIA & $\begin{array}{l}\text { Sí } \\
\text { Viviendas } \\
\text { de uso } \\
\text { turístico }\end{array}$ & $\begin{array}{l}\text { - Comunidad de propietarios } \\
\text { (art. 5.1.d)). } \\
\text { - Ubicación (suelo de uso } \\
\text { residencial (art. 2.a)). } \\
\text { - Prohibición en viviendas } \\
\text { protegidas (art. 5.1.e)). }\end{array}$ & $\begin{array}{l}\text { - Permitida la cesión compartida } \\
\text { (art. 3.b)). } \\
\text { - Habitabilidad y mantenimiento } \\
\text { (art. 6.m y n)). }\end{array}$ & $\begin{array}{c}\text { Sí } \\
\text { (art. 5.2) }\end{array}$ & $\begin{array}{l}\text { Decreto } 225 / 2019, \\
\text { de } 28 \text { de noviembre, } \\
\text { por el que se regulan } \\
\text { las viviendas de uso } \\
\text { turístico en el ámbito de } \\
\text { la Comunidad Autónoma } \\
\text { de Cantabria. }\end{array}$ \\
\hline
\end{tabular}


REALA. Nueva Época - N. ${ }^{014}$, octubre 2020 - ISSN: 1989-8975 - DOI: https://doi.org/10.24965/reala.i14.10784 - [Págs. 180-200]

Elementos comunes y diferencias de la respuesta regulatoria a los retos del alojamiento colaborativo y el alquiler de corta duración...

Andrea Kruithof Ausina

\begin{tabular}{|c|c|c|c|c|c|}
\hline & $\begin{array}{c}\text { Regulación } \\
\text { específica }\end{array}$ & Limitaciones urbanísticas & $\begin{array}{l}\text { Limitaciones } \\
\text { actividad }\end{array}$ & Inscripción & Regulación \\
\hline $\begin{array}{l}\text { CASTILLA } \\
\text { Y LEÓN }\end{array}$ & $\begin{array}{c}\text { Sí } \\
\text { Viviendas } \\
\text { de uso } \\
\text { turístico }\end{array}$ & $\begin{array}{l}\text { - Espacio turístico saturado } \\
\text { (art. 56, Ley de turismo). } \\
\text { Vinculado a problemas } \\
\text { medioambientales. }\end{array}$ & $\begin{array}{l}\text { Decreto 3/2017: } \\
\text { - Cesión integral (art.2.c)). } \\
\text { Afectado por Sentencia del TSJCyL. } \\
\text { - Requisitos técnicos mínimos } \\
\text { (art. 2.b y e, art. 16). } \\
\text { - Mantenimiento y limpieza } \\
\text { (art. 16.g). } \\
\text { - Capacidad (art. 16.3). } \\
\text { - Tiempo de alquiler mínimo } \\
\text { (art. 2.d)). } \\
\text { - Abierta la posibilidad de } \\
\text { autorización municipal (art. 7.1). } \\
\text { - Normas de convivencia } \\
\text { (art. 27.1 e)). } \\
\text { - Número máximo de viviendas } \\
\text { explotadas por un mismo titular } \\
\text { (art. 2.2.c)). }\end{array}$ & $\begin{array}{c}\text { Sí } \\
\text { (art. 6.6) }\end{array}$ & $\begin{array}{l}\text { Decreto } 3 / 2017, \text { de } \\
16 \text { de febrero, por el } \\
\text { que se regulan los } \\
\text { establecimientos de } \\
\text { alojamiento en la } \\
\text { modalidad de vivienda } \\
\text { de uso turístico en la } \\
\text { Comunidad de Castilla } \\
\text { y León. } \\
\text { Ley } 14 / 2010, \text { de } 9 \text { de } \\
\text { diciembre, de turismo de } \\
\text { Castilla y León. }\end{array}$ \\
\hline EXTREMADURA & No & No & $\begin{array}{l}\text { - Requisitos técnicos mínimos } \\
\text { (arts. 43, 44). } \\
\text { - Normas de convivencia (art. 14.d)). } \\
\text { - Exclusión de la cesión parcial } \\
\text { (art. 61). } \\
\text { - Seguridad, ref. genérica (art. 44). } \\
\text { - Normativa medioambiental, ref. } \\
\text { genérica (art. 44). }\end{array}$ & $\begin{array}{c}\text { Sí } \\
\text { (art. 52) }\end{array}$ & $\begin{array}{l}\text { Ley } 2 / 2011 \text {, de } 31 \text { de } \\
\text { enero, de desarrollo } \\
\text { y modernización del } \\
\text { turismo de Extremadura. } \\
\text { Ley } 6 / 2018 \text {, de } 12 \text { de } \\
\text { julio, de modificación } \\
\text { de la Ley } 2 / 2011 \text {, de } 31 \\
\text { de enero, de desarrollo } \\
\text { y modernización del } \\
\text { turismo de Extremadura. }\end{array}$ \\
\hline $\begin{array}{l}\text { ISLAS } \\
\text { BALEARS }\end{array}$ & $\begin{array}{c}\text { Sí } \\
\text { Estancias } \\
\text { turísticas } \\
\text { en viviendas }\end{array}$ & $\begin{array}{l}\text { Ley 8/2012: } \\
\text { - Zonas declaradas aptas de } \\
\text { manera expresa (art. 50.3, } \\
\text { art. 75)). } \\
\text { - Viviendas con infracciones } \\
\text { graves/muy graves } \\
\text { de legalidad urbanística } \\
\text { (art. 50.4). } \\
\text { - Comunidad de propietarios } \\
\text { (art. 50.7). } \\
\text { - Planes de intervención en } \\
\text { ámbitos turísticos: densidad } \\
\text { poblacional máxima, } \\
\text { delimitación zonal y ratios. } \\
\text { (art. 5.3 y 5.4). } \\
\text { - Zonas turísticas saturadas } \\
\text { o maduras (art. } 77 \text { ). } \\
\text { - Viviendas protegidas } \\
\text { (art. 50.8). }\end{array}$ & $\begin{array}{l}\text { Ley 8/2012: } \\
\text { - Tiempo máximo de alquiler } \\
\text { (art. 50.20) (modalidad de alquiler } \\
\text { de vivienda principal). } \\
\text { - Requisitos técnicos mínimos } \\
\text { (art. 52). } \\
\text { - Sostenibilidad ambiental mínima } \\
\text { (art. 50.5 y 50.6). } \\
\text { - Imposibilidad en pisos de } \\
\text { protección oficial/precio tasado } \\
\text { (art. 50.8). } \\
\text { - Usos de convivencia y orden } \\
\text { público (art. 16, art. 50.12). } \\
\text { - Antigüedad mínima del edificio } \\
\text { (art. 50.17). } \\
\text { - Mantenimiento y limpieza (art. 51). } \\
\text { - Capacidad máxima (art. 52). } \\
\text { - Exclusión de la cesión parcial } \\
\text { (art. 50.13, art. 50.13). } \\
\text { - Posibilidad de establecer } \\
\text { autorización (art. 23). } \\
\text { - Accesibilidad (ref. genérica, } \\
\text { art. 50.6). }\end{array}$ & $\begin{array}{c}\text { Sí } \\
\text { (art. 23.6, } \\
\text { art. } 27 \\
\text { (registro } \\
\text { por cada } \\
\text { cada isla) }\end{array}$ & $\begin{array}{l}\text { Llei 8/2012, de } 19 \text { de } \\
\text { juliol, del turisme de les } \\
\text { Illes Balears. } \\
\text { Llei 6/2017, de } 31 \text { de } \\
\text { juliol, de modificació de } \\
\text { la Llei 8/2012, de } 19 \text { de } \\
\text { juliol, del turisme de les } \\
\text { Illes Balears, relativa } \\
\text { a la comercialització } \\
\text { d'estades turístiques a } \\
\text { habitatges. } \\
\text { Acord del Ple de } \\
\text { Mallorca pel qual } \\
\text { s'aprova la delimitació } \\
\text { provisional de les } \\
\text { zones aptes per a } \\
\text { la comercialització } \\
\text { d'estades turístiques } \\
\text { en habitatges d'ús } \\
\text { residencial a Mallorca } \\
\text { (Exclosa Palma). }\end{array}$ \\
\hline
\end{tabular}


REALA. Nueva Época - N. ${ }^{014}$, octubre 2020 - ISSN: 1989-8975 - DOI: https://doi.org/10.24965/reala.i14.10784 - [Págs. 180-200]

Elementos comunes y diferencias de la respuesta regulatoria a los retos del alojamiento colaborativo y el alquiler de corta duración...

Andrea Kruithof Ausina

\begin{tabular}{|c|c|c|c|c|c|}
\hline & $\begin{array}{l}\text { Regulación } \\
\text { específica }\end{array}$ & Limitaciones urbanísticas & $\begin{array}{l}\text { Limitaciones } \\
\text { actividad }\end{array}$ & Inscripción & Regulación \\
\hline PALMA & $\begin{array}{c}\text { Sí } \\
\text { Pla general } \\
\text { per a } \\
\text { la regulació } \\
\text { aplicable als } \\
\text { establiments } \\
\text { turístics } \\
\text { i albergs } \\
\text { juvenils } \\
\text { a Palma }\end{array}$ & $\begin{array}{l}\text { Art. } 55 \text { y sig. Cuadros de usos: } \\
\text { - Tipología de edificio: } \\
\text { Prohibición en viviendas } \\
\text { plurifamiliares. } \\
\text { - Regulación zonal de nuevas } \\
\text { licencias (prohibición en centro } \\
\text { histórico, excepto edificios con } \\
\text { máximo de } 20 \text { habitaciones). } \\
\text { - Viviendas unifamiliares en } \\
\text { suelo residencial. } \\
\text { - Medidas ambientales para } \\
\text { nuevos proyectos. } \\
\text { - Índice de intensidad } \\
\text { alojamientos turísticos por } \\
\text { parcela (1 plaza/40 } \mathrm{m}^{2} \\
\text { construidos) }\end{array}$ & No & Sí & $\begin{array}{l}\text { Acord, aprovat pel Ple } \\
\text { de l'Ajuntament de } \\
\text { Palma en data } 26 \text { de } \\
\text { juliol de } 2018, \text { de la } \\
\text { Delimitació provisional } \\
\text { de les zones aptes per } \\
\text { a la comercialització de } \\
\text { les estades turístiques } \\
\text { en habitatges d'ús } \\
\text { residencial al municipi } \\
\text { de Palma (Exp. 25815). }\end{array}$ \\
\hline FORMENTERA & \begin{tabular}{|} 
Reglamento \\
$1 / 2015$ \\
por el que \\
se regula la \\
comercialización \\
de estancias \\
turísticas en \\
viviendas \\
en la Isla de \\
Formentera
\end{tabular} & $\begin{array}{l}\text { - Número máximo de viviendas } \\
\text { comercializables en una misma } \\
\text { parcela (art. } 5.2 \mathrm{c}) \text { ). }\end{array}$ & $\begin{array}{l}\text { - Requisitos técnicos mínimos } \\
\text { (art. 2, que remite a Ley } \\
\text { autonómica de turismo, art. 5.2), } \\
\text { a incluir en un Plan de Calidad } \\
\text { (arts. 3-4). } \\
\text { Plan de calidad: } \\
\text { - Condiciones en función de la } \\
\text { tipología de vivienda (art. 5). } \\
\text { - Dotaciones mínimas de mobiliario } \\
\text { y utensilios (art. 4). } \\
\text { - Requisitos mínimos que acrediten } \\
\text { la limpieza y el mantenimiento } \\
\text { (art. 4). }\end{array}$ & $\begin{array}{c}\text { Sí } \\
\text { (art. 6) }\end{array}$ & $\begin{array}{l}\text { Plan de calidad para } \\
\text { las viviendas objeto } \\
\text { de comercialización } \\
\text { turística para el periodo } \\
\text { 2015-2019. }\end{array}$ \\
\hline GALICIA & $\begin{array}{l}\text { Sí } \\
\text { Viviendas } \\
\text { de uso } \\
\text { turístico }\end{array}$ & $\begin{array}{l}\text { - Suelo residencial (art. 5.6). } \\
\text { - Limitación en número } \\
\text { por edificio o sector } \\
\text { (Ayuntamientos) (art. 5.6). } \\
\text { - Comunidad de vecinos } \\
\text { (art. 41.5). } \\
\text { - Regulación urbanística, } \\
\text { ref. genérica (art. 2.2). }\end{array}$ & $\begin{array}{l}\text { - Tiempo de alquiler máximo } \\
\text { (art. 5.2). } \\
\text { - Cesión integral (art. 5.1). } \\
\text { - Requisitos técnicos mínimos } \\
\text { (art. 39, art. 5.1). } \\
\text { - Normas de convivencia (art. 40.5). } \\
\text { - Mantenimiento (art. 39). } \\
\text { - Posibilidad de autorización } \\
\text { (art. 42.1). }\end{array}$ & $\begin{array}{c}\text { Sí } \\
\text { (art. 43) }\end{array}$ & $\begin{array}{l}\text { Decreto 12/2017, de } 26 \\
\text { de enero, por el que se } \\
\text { establece la ordenación } \\
\text { de apartamentos } \\
\text { turísticos, viviendas } \\
\text { turísticas y viviendas } \\
\text { de uso turístico en la } \\
\text { Comunidad Autónoma } \\
\text { de Galicia. }\end{array}$ \\
\hline PAÍS VASCO & $\begin{array}{c}\text { Sí } \\
\text { Viviendas y } \\
\text { habitaciones } \\
\text { de viviendas } \\
\text { particulares } \\
\text { para uso } \\
\text { turístico }\end{array}$ & $\begin{array}{l}\text { Decreto 101/2018: } \\
\text { - Normativa municipal sobre } \\
\text { edificación (8.2.a) y b)). } \\
\text { - Requisitos medioambientales } \\
\text { (8.2.d)). } \\
\text { - Comunidad de vecinos } \\
\text { (art. 19). }\end{array}$ & $\begin{array}{l}\text { Decreto 101/2018: } \\
\text { - Requisitos técnicos mínimos } \\
\text { (art. 12, arts. 14-15). } \\
\text { - Habilitación previa en casos } \\
\text { concretos (8.1). } \\
\text { - Residencia y empadronamiento } \\
\text { para alquiler de habitaciones } \\
\text { (art. 3). } \\
\text { - Capacidad máxima (art. 13). } \\
\text { - Mantenimiento } \\
\text { (art. 53.11 en la Ley). } \\
\text { - Normas de convivencia (art. 16. en } \\
\text { la ley, art. } 24 \text { en decreto). }\end{array}$ & $\begin{array}{l}\text { Sí } \\
\text { (art. 23.3 } \\
\text { en la Ley } \\
\text { de Turismo, } \\
\text { art. } 7 \text { en el } \\
\text { Decreto) }\end{array}$ & $\begin{array}{l}\text { Decreto } 101 / 2018, \text { de } \\
3 \text { de julio, de viviendas } \\
\text { y habitaciones de } \\
\text { viviendas particulares } \\
\text { para uso turístico. } \\
\text { Ley } 13 / 2016 \text {, de } 28 \text { de } \\
\text { julio, de Turismo. }\end{array}$ \\
\hline
\end{tabular}


REALA. Nueva Época - N. ${ }^{014}$, octubre 2020 - ISSN: 1989-8975 - DOI: https://doi.org/10.24965/reala.i14.10784 - [Págs. 180-200]

Elementos comunes y diferencias de la respuesta regulatoria a los retos del alojamiento colaborativo y el alquiler de corta duración...

Andrea Kruithof Ausina

\begin{tabular}{|c|c|c|c|c|c|}
\hline & $\begin{array}{l}\text { Regulación } \\
\text { específica }\end{array}$ & Limitaciones urbanísticas & $\begin{array}{l}\text { Limitaciones } \\
\text { actividad }\end{array}$ & Inscripción & Regulación \\
\hline BILBAO & Sí & $\begin{array}{l}\text { - Ubicación: } 1 .^{\text {a }} \text { planta de } \\
\text { edificios residenciales o } \\
\text { plantas inferiores a viviendas } \\
\text { (art. 6.3.24). } \\
\text { - Limitación de número de } \\
\text { licencias turísticas en función } \\
\text { de zona (Casco Viejo y en } \\
\text { Bilbao La Vieja). }\end{array}$ & $\begin{array}{l}\text { - Informe urbanístico de } \\
\text { conformidad (art. 6.3.24). } \\
\text { - Permitida la cesión parcial, máx. } 3 \\
\text { places (art. 6.3.18). } \\
\text { - Remite a regulación sectorial } \\
\text { (art. 6.3.24). }\end{array}$ & $\begin{array}{c}\text { Sí } \\
\text { (art. 6.3.24) }\end{array}$ & $\begin{array}{l}\text { Plan General de } \\
\text { Ordenación Urbana de } \\
\text { Bilbao. }\end{array}$ \\
\hline $\begin{array}{l}\text { SAN } \\
\text { SEBASTIÁN }\end{array}$ & $\begin{array}{l}\text { Sí } \\
\text { Ordenanza } \\
\text { reguladora } \\
\text { del uso } \\
\text { urbanístico de } \\
\text { vivienda } \\
\text { turística y } \\
\text { alquiler de } \\
\text { habitaciones } \\
\text { en vivienda } \\
\text { habitual } \\
\text { para uso } \\
\text { turístico } \\
\text { Afectado por } \\
\text { sentencia }\end{array}$ & $\begin{array}{l}\text { - Solo plantas bajas o edificios } \\
\text { con acceso independiente. } \\
\text { - División zonal de usos (PGOU, } \\
\text { arts. 59-60) y requisitos } \\
\text { (arts. 13-15 ordenanza): } \\
\text { - A: Prohibidos nuevos } \\
\text { establecimientos. } \\
\text { - B: situadas por bajo de uso } \\
\text { residencial. Viviendas de } \\
\text { máximo } 250 \text { m². }^{2} \text {. } \\
\text { - B: Permiso en plantas } \\
\text { superiores si el edificio tiene } \\
\text { mínimo } 7 \text { plantas. Permitidos } \\
\text { hasta } 2 \text { viviendas por cada } 6 \\
\text { plantas adicionales. Viviendas } \\
\text { inferiores a } 350 \text { m². }^{2} \text {. }\end{array}$ & $\begin{array}{l}\text { Ordenanza: } \\
\text { - Informe urbanístico de } \\
\text { conformidad (art. 19). } \\
\text { - Requisitos de equipamientos } \\
\text { mínimos: estancia, cocina, } \\
\text { comedor, dormitorio doble, cuarto } \\
\text { de baño y tendedor. Tamaño } \\
\text { mínimo: } 35 \text { m² }^{2} \text { (arts. 13-15). } \\
\text { - Permitida la cesión parcial, con } \\
\text { requisito de empadronamiento y } \\
\text { residencia habitual del propietario } \\
\text { (art. 2). } \\
\text { - Impacto ambiental y acústico } \\
\text { (BOG de } 17 \text { de octubre de 2000). }\end{array}$ & (art. 19) & $\begin{array}{l}\text { Plan General de } \\
\text { Ordenación Urbana de } \\
\text { San Sebastián. } \\
\text { Ordenanza reguladora } \\
\text { de la actuación } \\
\text { municipal frente a la } \\
\text { contaminación acústica } \\
\text { por ruidos y vibraciones. }\end{array}$ \\
\hline $\begin{array}{l}\text { COMUNIDAD } \\
\text { VALENCIANA }\end{array}$ & Sí & $\begin{array}{l}\text { Planes municipales de } \\
\text { ordenación de recursos } \\
\text { turísticos (art. 27) / planes de } \\
\text { intervención: Conclusiones } \\
\text { podrán incorporarse al PGOU. } \\
\text { Opción a delimitación zonal } \\
\text { (ámbitos turísticos y de } \\
\text { protección, zonas saturadas); } \\
\text { densidades máximas de } \\
\text { población, número de plazas, } \\
\text { características edificatorias. }\end{array}$ & $\begin{array}{l}\text { Ley 15/2018: } \\
\text { - Mantenimiento (art. 56) y } \\
\text { habitabilidad (art. 65). } \\
\text { - Sostenibilidad (art. 57). } \\
\text { - Referencia genérica a la normativa } \\
\text { en seguridad, legislación laboral, } \\
\text { seguridad, precios y fiscalidad } \\
\text { (art. 58). } \\
\text { - Informe de compatibilidad } \\
\text { urbanística (art. 65). } \\
\text { - Exclusión de la cesión parcial } \\
\text { (art. 65). } \\
\text { - Normas de convivencia } \\
\text { (art. 17.e) y g)). } \\
\text { Decret 92/2009: } \\
\text { - Requisitos técnicos mínimos } \\
\text { (Anexo I). }\end{array}$ & $\begin{array}{c}\text { Sí } \\
\text { (art. 53) }\end{array}$ & $\begin{array}{l}\text { Ley } 15 / 2018, \text { de } 7 \text { de } \\
\text { junio, de turismo, ocio } \\
\text { y hospitalidad de la } \\
\text { Comunitat Valenciana. } \\
\text { Decreto 92/2009, de } \\
3 \text { de julio, del Consell, } \\
\text { por el que aprueba el } \\
\text { reglamento regulador } \\
\text { de las viviendas } \\
\text { turísticas denominadas } \\
\text { apartamentos, villas, } \\
\text { chalés, bungalows } \\
\text { y similares, y de las } \\
\text { empresas gestoras, } \\
\text { personas jurídicas } \\
\text { o físicas, dedicadas } \\
\text { a la cesión de su } \\
\text { uso y disfrute, en el } \\
\text { ámbito territorial de la } \\
\text { Comunitat Valenciana. }\end{array}$ \\
\hline VALÈNCIA & $\begin{array}{l}\text { Vivienda } \\
\text { turística }\end{array}$ & $\begin{array}{l}\text { - Ubicación: plantas bajas o } \\
\text { primeras plantas completas } \\
\text { (siempre por debajo de uso } \\
\text { residencial) (capítulo 6 PGOU). } \\
\text { - Usos del suelo por zonas. } \\
\text { En Ciutat Vella: } \\
\text { - Domicilio habitual } \\
\text { (art. 6.4.3.c.V1.1). } \\
\text { - } 60 \text { días al año } \\
\text { (art. 6.4.3.c.V1.2). }\end{array}$ & - Licencia (art. 1.6 PGOU). & & $\begin{array}{l}\text { PGOU València. } \\
\text { Plan Especial de } \\
\text { Protección y Catálogo } \\
\text { de Protecciones Ciutat } \\
\text { Vella de València. }\end{array}$ \\
\hline
\end{tabular}


REALA. Nueva Época - N. 14, octubre 2020 - ISSN: 1989-8975 - DOI: https://doi.org/10.24965/reala.i14.10784 - [Págs. 180-200]

Elementos comunes y diferencias de la respuesta regulatoria a los retos del alojamiento colaborativo y el alquiler de corta duración...

Andrea Kruithof Ausina

\section{REFERENCIAS BIBLIOGRÁFICAS}

ARANA GARCÍA, E. (2018): "La intervención local en las viviendas de uso turístico a través de la zonificación urbanística: requisitos y consecuencias”, en Revista de estudios de la Administración Local y Autonómica, núm. 10, págs. 6-21. DOI: https://doi.org/10.24965/reala.v0i10.10545.

ARTIGOT GOLOBARDES, M. (2017): "Retos de las Viviendas Turísticas en Barcelona: Entre el Mercado y la Regulación", en Papeles de Economía Española, núm. 151, págs. 189-206. DOI: https://doi.org/10.2139/ ssrn.2957677.

ARTIGOT GOLOBARDES, M. (2018): "Implicaciones normativas de la heterogeneidad del mercado de alquiler de viviendas turísticas en Barcelona”, en DE LA ENCARNACIÓN, A. M. (dir.); BOIX, A. (ed.): La regulación del alojamiento colaborativo, viviendas de uso turístico y alquiler de corta estancia en el derecho español, págs. 149169. Pamplona: Editorial Aranzadi.

BOIX PALOP, A. (2018): "Estrategias regulatorias para la resolución de los conflictos de intereses generados por la proliferación del alojamiento de corta duración con intermediación digital", en DE LA ENCARNACIÓN, A. M. (dir.); BOIX, A. (ed.): La regulación del alojamiento colaborativo, viviendas de uso turístico y alquiler de corta estancia en el derecho español, págs. 261-293. Pamplona: Editorial Aranzadi.

CNMC (2018): Estudio sobre la regulación de las viviendas de uso turístico en España. Madrid: CNMC, Fecha de consulta: 06-07-2020. URL: https://www.cnmc.es/sites/default/files/2133063 3.pdf.

CONSEJO INSULAR DE FORMENTERA (2018): "Aprobación definitiva del estudio de detalle y escritura de reparcelación voluntaria con el fin de desarrollar la unidad de actuación denominada UA SFC-06 de Sant Francesc; TM Formentera", en BOLETÍN OFICIAL DE LAS ISLAS BALEARES (BOIB), núm. 093- 28 de julio. URL: https://www.caib.es/eboibfront/pdf/es/2018/93/1013868.

DE LA ENCARNACIÓN, A. M. (2016): "El alojamiento colaborativo: Viviendas de uso turístico y plataformas virtuales", en Revista de estudios de la Administración Local y Autonómica, núm 5, págs. 30-55. DOI: https://doi. org/10.24965/reala.v0i5.10350.

DE LA ENCARNACIÓN, A. M. (2018): "Soluciones europeas en materia de regulación del alojamiento "colaborativo»: París y Londres", en DE LA ENCARNACIÓN, A. M. (dir.); BOIX, A. (ed.): La regulación del alojamiento colaborativo, viviendas de uso turístico y alquiler de corta estancia en el derecho español, págs. 189-209. Pamplona: Editorial Aranzadi.

DEL ÁGUILA OBRA, A. R. (2016): "Economía digital: estrategia empresarial y modelos de negocio", en Gaceta sindical, reflexión y debate, núm. 27, págs. 217-228. URL: https://www.ccoo.es/152806c7bbdfac28c2bde95f40e00 c0d000001.pdf.

DEL BUSTO, E.; CEBALLOS MARTÍN, M. M.; PÉREZ GUERRA, R. (2019): "Marco normativo de los apartamentos y viviendas de uso turístico en España. especial mención a la Comunidad Autónoma de Madrid", en Journal of Tourism Analysis: Revista de Análisis Turístico, vol. 26, núm. 1, págs. 62-92. DOI: https://doi.org/10.1108/JTA-052018-0015.

DOMÉNECH PASCUAL, G. (2015): “Economía colaborativa y Administración local”, en Anuario del Gobierno Local 2015/2016, núm. 1, págs. 35-66. Fundación Democracia y Gobierno Local.

GIL, J.; SEQUERA, J. (2018): "Expansión de la ciudad turística y nuevas resistencias. El caso de Airbnb en Madrid", en Empiria, Revista de Metodología de Ciencias Sociales, núm. 41, págs. 15-32, DOI: https://doi.org/10.5944/ empiria.41.2018.22602.

GIMENO FERNÁNDEZ, C. (2018): "La regulación de las viviendas de uso turístico en la Comunidad Valenciana", en DE LA ENCARNACIÓN, A. M. (dir.); BOIX, A. (ed.): La regulación del alojamiento colaborativo, viviendas de uso turístico y alquiler de corta estancia en el derecho español, págs. 325-267. Pamplona: Editorial Aranzadi.

GUILLÉN NAVARRO, N. A. (2018): "Ámbito objetivo del contrato de alojamiento turístico: ¿Qué viviendas se pueden arrendar?", en CERDEIRA BRAVO DE MANSILLA, G. (dir.); GARCÍA MAYO, M. (coord.): Viviendas de uso turístico: régimen civil, administrativo y fiscal, págs. 231-267. Madrid: Editorial Reus.

GUILLÉN NAVARRO, N. A. (2018): "La vivienda con un uso turístico: entre el turismo "colaborativo» y la competencia desleal, pequeños propietarios, grandes plataformas en internet y la respuesta normativa ante el caos regulatoria”, en CERDEIRA BRAVO DE MANSILLA, G. (dir.); GARCÍA MAYO, M. (coord.): Viviendas de uso turístico: régimen civil, administrativo y fiscal, págs. 19-54. Madrid: Editorial Reus.

GURRAN, N.; PHIBBS, P. (2017): “When Tourists Move In: How Should Urban Planners Respond to Airbnb?”, en Journal of the American Planning Association, vol. 83, núm. 1, págs. 80-92. DOI: https://doi.org/10.1080/01944363 .2016.1249011.

GUTTENTAG, D. (2015): "Airbnb: disruptive innovation and the rise of an informal tourism accommodation sector", en Current Issues in Tourism, vol. 18, núm. 12, págs. 1.192-1.217. DOI: https://doi.org/10.1080/13683500.2013.827159.

HERRERO SUÁREZ, C. (2017): "Las viviendas de uso turístico: ¿el enemigo a abatir? Reflexiones sobre la normativa autonómica en materia de alojamientos turísticos", en Revista de Estudios Europeos, núm. 70, págs. 150-162.

NOGUEIRA LOPEZ, A. (2018): "Las competencias sobre el alojamiento "colaborativo». Entre el "derecho a la ciudad», la garantía de la vivienda y la dura lex económica”, en DE LA ENCARNACIÓN, A. M. (dir.); BOIX, A. 
REALA. Nueva Época - N. 14, octubre 2020 - ISSN: 1989-8975 - DOI: https://doi.org/10.24965/reala.i14.10784 - [Págs. 180-200]

Elementos comunes y diferencias de la respuesta regulatoria a los retos del alojamiento colaborativo y el alquiler de corta duración...

Andrea Kruithof Ausina

(ed.): La regulación del alojamiento colaborativo, viviendas de uso turístico y alquiler de corta estancia en el derecho español, págs. 149-169. Pamplona: Editorial Aranzadi.

ROMÁN MÁRQUEZ, A. (2016): "Planificación urbanística del turismo: la regulación de las viviendas de uso turístico en Madrid y Barcelona”, en Revista de estudios de la Administración Local y Autonómica, núm. 10, págs. 22-39. DOI: https://doi.org/10.24965/reala.v0i10.10566.

SÁNCHEZ JORDÁN, M. ${ }^{a}$ E.; GARCÍA GARCÍA, J. A. (2018): "La cesión de viviendas con fines turísticos: concepto, naturaleza y delimitación frente a figuras afines", en CERDEIRA BRAVO DE MANSILLA, G. (dir.); GARCÍA MAYO, M. (coord.): Viviendas de uso turístico: régimen civil, administrativo y fiscal, págs. 19-54. Madrid: Editorial Reus.

SORIANO ARNAZ, A. (2018): "Medidas de control y acceso al mercado del alojamiento "colaborativo»: la declaración responsible y el registro en la Comunidad Valenciana", en DE LA ENCARNACIÓN, A. M. (dir.); BOIX, A. (ed.): La regulación del alojamiento colaborativo, viviendas de uso turístico y alquiler de corta estancia en el derecho español, págs. 149-169. Pamplona: Editorial Aranzadi.

ZERVAS, G.; PROSERPIO, D.; BYERS, J. (2017): "The Rise of the Sharing Economy: Estimating the Impact of Airbnb on the Hotel Industry", en Journal of Marketing Research, DOI: https://doi.org/10.1509/jmr.15.0204. 